(c) <2021 > . This manuscript version is made available under the CC-BY-NC-ND 4.0 license http://creativecommons.org/licenses/by-nc-nd/4.0/

The definitive publisher version is available online at https://doi.org/ 10.1016/j.energy.2021.120932 


\title{
A Comprehensive Investigation of Energy Management Practices within Energy Intensive Industries in Bangladesh
}

\author{
A S M Monjurul Hasan ${ }^{1 *}$, Rashedul Amin Tuhin ${ }^{2}$, Mahfuz Ullah ${ }^{3}$, Taiyeb Hasan Sakib ${ }^{4}$, \\ Patrik Thollander ${ }^{5,6}$, Andrea Trianni ${ }^{1}$
}

1 School of Information, Systems and Modelling, Faculty of Engineering and IT, University of Technology Sydney, 2007 Ultimo, NSW, Australia

2 Department of Computer Science and Engineering, East West University, Dhaka, 1215, Bangladesh.

3 Department of Electrical \& Electronic Engineering, Bangladesh Army International University of Science \& Technology, Cumilla, Bangladesh.

4 Department of Electrical \& Electronic Engineering, Islamic University of Technology, Gazipur, Bangladesh.

5 Division of Energy Systems, Department of Management and Engineering, Linköping University, Linköping SE-581 83, Sweden

6 Department of Building, Energy and Environment Engineering, University of Gävle, 80176 Gävle, Sweden.

* Correspondence: asmmonjurul.hasan@uts.edu.au

\begin{abstract}
:
Industrial energy efficiency is acknowledged as a cost-effective mean contributing to sustainable development and industrial competitiveness. Implementing energy management practices becomes even more imperative for developing countries, considering their energy usage trends and economic development forecasts. Based on the circumstances, an empirical investigation is conducted on energy efficiency and management practices, as well as barriers and drivers to energy efficiency in the energyintensive industries of Bangladesh. The study finds that majority of the companies barely implement the energy management practices. Energy audits represent the mostly implemented energy management practice at the industries, though a comprehensive approach on a detailed level is still lacking. In addition, this study finds that the number of dedicated and specialised energy professionals employed in the industries is yet negligible. The cumulated results show that energy efficiency is mostly disrupted due to inadequate support from preeminent administration and bureaucratic intricacy. Energy blueprint cost-saving due to less use of energy and rules and regulations were distinctively signified as most imperative drivers for energy efficiency. On the other hand, lack of information is found to be the most significant barrier to consult energy service companies. Analysis of the country's energy usage and supply-demand relationship points towards insufficient energy efficiency measures and energy management practices in the country. The study also finds that energy efficiency could be improved by $8 \%$ to $10 \%$ through the practice of energy management. Our findings, besides pointing out specific issues to be tackled in the specific context of investigation, pave the way for further research over industrial energy efficiency in developing countries.
\end{abstract}

Keywords: energy management; industrial efficiency; energy-intensive industry; energy policy; sustainability. 


\section{Introduction}

After maintaining a Gross Domestic Product (GDP) growth rate of over six percent for the recent years, in the year of 2017-18, Bangladesh attained a GDP of nearly $8 \%$ and is set to become the 3rd fastest growing economy in the world [1]. With this continuous economic growth, Bangladesh is working towards a goal of entering into the league of middle-income countries by the year 2021. When this target is attained, the per capita annual income of the country is expected to be more than 2000 USD, and this requires a demand for sustainable energy supply in the country. An increased supply of energy is a must to go hand in hand with the accelerated efforts for the development and growth of a fastmoving economy [2].

There are scopes for improvement in the energy generation sector in Bangladesh and the country is yet to achieve its best in this sector [3]. Based on the GDP growth rate, it is forecasted that the energy usage in Bangladesh is going to be increased significantly over the coming years [4]. By 2030, the peak demand is expected to be 33,700 MW which is distinctively greater than the peak demand in 2010 [5]. The number of industrial companies has notably increased after 1995, causing high energy demand throughout the country. The annual increase of $8 \%$ in electricity demand gives an estimated projection of 22,500 MW demand in 2021 where approximately $40 \%$ is consumed by the industries [6]. As indicated by recent governmental reports in Bangladesh [7], to sustain the status of lower-middleincome country (for a per capita income of 2000 USD) in 2021, the total use of energy should be 105.5 Mtoe for a population of 171 million. Whereas, the projected energy supply in 2021 would be of 88 Mtoe, indicating an apparent lack of energy supply in the existing setup of planning.

The upswing of energy cost and sustainability have impelled industries to find other ways to address energy consumption. It is common knowledge that energy efficiency helps to build a bridge between economics, energy security [7] and environmental objectives [8]. Besides, energy efficiency analysis helps to figure out the possible sectors for energy consumption reduction without hampering energy productivity [10]. Nonetheless, energy efficiency exploration assists the life cycle cost comprehensively in the production process [11]. Unfortunately, many developing countries are still indisposed to benefit the available opportunities offered in the energy efficiency domain due to lack of knowledge and awareness in energy management. Research has shown that the reduction in industrial energy usage can be obtained not only by a greater diffusion of more energy-efficient technological equipment [12], but also through a combination of more efficient energy behaviour and management of the energy resource in the industry [13]. Therefore, it is of utmost importance to take the necessary initiatives in order to implement industrial energy efficiency measures and energy management practices in every possible sector [14].

Several studies have been conducted at multiple demographic locations on industrial energy management practices and how effectively these are carried out. Thollander and Ottosson studied the Swedish energy intensive industries to explore energy management aspects [15]. Cagno et al. studied the barriers and drivers to industrial energy efficiency in the Netherlands [16]. In another study by Trianni et al. barriers to energy efficiencies in foundries at the European context are explored [17]. Rohdin and Thollander investigated the barriers and drivers to energy efficiency in the Swedish foundry industry [8]. Cooremans and Schönenberger focused on energy efficiency in the context of Switzerland [18]. Also, one study studied barriers to energy management in the Swedish pulp and paper industry [19]. Notably, the majority of the previous studies have addressed energy management indistinctly and a comprehensive study is needed in this domain. Moreover, the past and contemporary studies discussed the developed economies mainly. To the best of author's knowledge, yet only a minimal number of studies have addressed energy management and its practices comprehensively in developing countries, with just a few contributions carried out respectively on textile industries [3], SMEs [20], and Ghana's largest industry park [21]. Also, researchers are starting to explore this topic in Bangladesh [2], but literature is far from being mature, offering ample room for further research. Considering the economic 
growth and industrial advancement in recent days at Bangladesh, this is the high time to look through the energy sector comprehensively and explore the energy domain. Besides, as a developing economy, the learnings can be suited to other emerging economies. In this context, there is a need for in-depth study investigating methods for improving the present energy management practices at the industry offering empirical knowledge in support of academia, industrial decision-makers as well as policymakers.

We aim at giving a contribution to this research domain by investigating practices for energy management and energy efficiency within the industries of Bangladesh, which are heavily energy reliant. In this study, four key research topics have been explored, which are:

- The probable outcomes of energy management practices in the industries of Bangladesh that are energy-intensive.

- The current states of the industrial processes that are influenced by the actions and technologies related to energy efficiency.

- The availability of a long-term energy strategy at the industries.

- The barriers to implementing energy management practices at the industries.

The remaining sections of the paper are structured as follows: Section 2 is comprised of state of the art about energy management and practices in the industries. The methodology is presented in Section 3. Result and discussion comprised of Section 4 to Section 8. Within these sections, energy management is presented in Section 4, barriers to energy efficiency is discussed in Section 5, drivers to energy efficiency is presented in Section 6, energy efficiency potential is discussed in Section 7 and barriers to energy service companies are presented in Section 8. Finally, conclusions, study limitations and opportunities for further research are presented in Section 9.

\section{Literature background}

In this section, the characterisation of energy management, drivers and barriers to industrial energy efficiency, and energy service companies (ESCOs) are discussed.

\subsection{Energy Management Characterisation}

Energy management is an integral part of industrial production, including the logistics and environmental management system [22]. The cost reduction in operational management is the primary motivation to incorporate energy management into practice at the industries [23]. Energy management can be characterised as the proceedings to work specifically on energy-related issues of industry and considered as one of the key in-house activities for cost-effectiveness and energy efficiency improvement [15]. In this study, energy management is considered as applying to resources, conversion and utilization. It involves measuring, monitoring, logging, analysing, and controlling the energy flows through a system of an industry. Academics have addressed the definition of industrial energy management that varies from literature to literature, as it consists multiple factors. Schulze et al. [24] have compiled few of the selected definitions of industrial energy management. In one definition, industrial energy management is defined as the accumulation of planned \& executed actions for guaranteeing minimum energy input for a predetermined performance. According to them, energy management is also the strategy of meeting energy demand whenever it is necessary. In another attempt, they termed energy management as "The judicious and effective use of energy" ensuring maximisation of profits and optimisation of energy efficiency [24].

Multiple factors are needed to be incorporated for successful energy management [24] and energy optimisation [25]. The requirements to implement a meaningful and effective energy management system in the industries are articulated at academic literature. The minimum requirements are sustainable tactical planning, energy auditing, planning and implementing projects related to energy, identifying the key point indicators (KPIs), scrutinising the energy consumption, reporting to 
management, ensuring support from the upper management, establishing the provision of a dedicated energy manager, formulating policies that are friendly towards energy efficiency and so on. Figure 1 illustrates the essential activities for a successful energy management system.

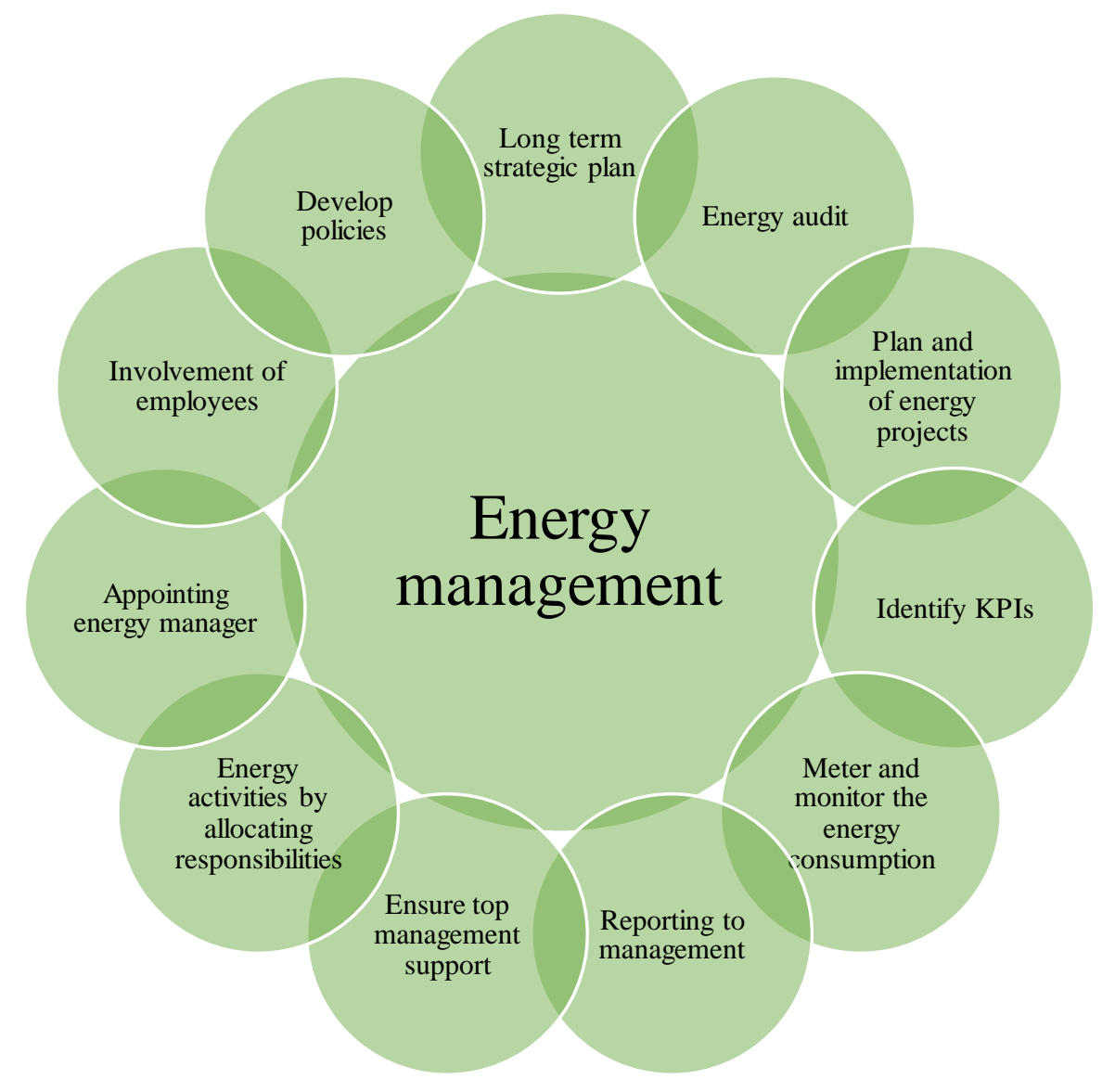

Figure 1: Key factors for successful energy management system [15], [27]-[29]

A model was proposed in a recent study to assess industrial energy management based on the criterion of energy management practice [9]. In this study, three characteristics have been considered. The model was incorporated by energy management practice adoption, followed by the establishment of a benchmark for adoption. The salient features of this model are the assessment of energy management practice adoption and energy management matrix model.

There are countries which have implemented an energy management system in various industries and got a good result in energy savings. In Denmark, about four hundred companies opted for an energy management system by 2001 and these companies used to consume $60 \%$ of the total energy in the whole country. The savings in energy that these companies made ranged from $24 \%$ to $62 \%$ [2]. Moreover, relevant scientific literature have presented that $40 \%$ of energy can be saved with the employment of proper energy management scheme in the industrial sector [30].

In the research domain of energy usage and improving energy efficiency, the researchers focused on the diffusion of cost-effective technologies. However, combined approach of technology [31] and energy management practices have greater impacts to endure the industrial energy efficiency [32]. Nonetheless, there are very little studies (see Table 1) that have actually focused on energy management practices in the industries till now. 
Table 1. Selected studies on energy management practices in the industries

\begin{tabular}{|c|c|c|c|}
\hline Study & Research Focus & Remark & Reference \\
\hline $\begin{array}{l}\text { Thollander and } \\
\text { Ottosson }\end{array}$ & $\begin{array}{l}\text { Foundry, pulp } \\
\text { and paper }\end{array}$ & $\begin{array}{l}40 \% \text { mills and } 25 \% \text { foundries are } \\
\text { successful in energy management. }\end{array}$ & [15] \\
\hline Brunke et al. & $\begin{array}{l}\text { Iron \& steel } \\
\text { industry }\end{array}$ & $\begin{array}{l}\text { Companies are vigorously affianced in } \\
\text { energy management and its practices, } \\
\text { nonetheless there are scopes for } \\
\text { improvement in prioritisation and } \\
\text { awareness within the organisation. }\end{array}$ & [27] \\
\hline $\begin{array}{l}\text { Christoffersen et } \\
\text { al. }\end{array}$ & $\begin{array}{l}304 \text { industrial } \\
\text { firms }\end{array}$ & $\begin{array}{l}\text { Among the industries between } 3 \% \text { and } \\
14 \% \text { practice energy management. }\end{array}$ & {$[28]$} \\
\hline $\begin{array}{l}\text { Ates and } \\
\text { Durakbasa }\end{array}$ & $\begin{array}{l}\text { Cement, paper \& } \\
\text { pulp, ceramics, } \\
\text { ISI, and textile } \\
\text { industries }\end{array}$ & $\begin{array}{l}\text { Degree of energy management solicitation } \\
\text { is } 22 \% \text {. }\end{array}$ & [29] \\
\hline Lawrence et al. & $\begin{array}{l}\text { Pulp and paper } \\
\text { industry }\end{array}$ & $\begin{array}{l}\text { Specific energy consumption (SEC) is } \\
\text { discussed in relation to industrial energy } \\
\text { efficiency. Challenges emanate from a } \\
\text { lack of information about how SEC is } \\
\text { calculated. }\end{array}$ & [33] \\
\hline Lawrence et al. & $\begin{array}{l}\text { Pulp and paper } \\
\text { industry }\end{array}$ & $\begin{array}{l}\text { Presence of possible disparity between } \\
\text { farm characteristics that are perceived as } \\
\text { barriers to energy management. }\end{array}$ & [34] \\
\hline Backlund et al. & $\begin{array}{l}\text { Energy intensive } \\
\text { and non-energy } \\
\text { intensive } \\
\text { industries }\end{array}$ & $\begin{array}{l}70 \% \text { of industries have fulltime energy } \\
\text { manager, } 70 \% \text { of industries imply to } \\
\text { energy strategy }\end{array}$ & [35] \\
\hline Sivill et al. & $\begin{array}{l}\text { Pulp \& paper, } \\
\text { basic metals, and } \\
\text { petro- chemicals } \\
\text { industries. }\end{array}$ & $\begin{array}{l}\text { Performance measurement in energy is } \\
\text { the third development precedence in } \\
\text { energy management. }\end{array}$ & [36] \\
\hline Lawrence et al. & Pulp \& paper & $\begin{array}{l}\text { Energy management is not always } \\
\text { implemented due to presence of barriers. }\end{array}$ & [37] \\
\hline Sannö et al. & $\begin{array}{l}\text { Volvo CE- a } \\
\text { multinational } \\
\text { industrial } \\
\text { corporation }\end{array}$ & $\begin{array}{l}\text { Introduction of energy management } \\
\text { program led to more efficient energy } \\
\text { management. The critical elements that } \\
\text { characterise efficient energy management } \\
\text { were found in the corporate group after } \\
\text { the introduction of energy management } \\
\text { program. }\end{array}$ & {$[38]$} \\
\hline $\begin{array}{l}\text { Andersson and } \\
\text { Thollander }\end{array}$ & $\begin{array}{l}\text { Pulp and paper } \\
\text { industry }\end{array}$ & $\begin{array}{l}25 \% \text { of the mills apply best practice } \\
\text { regarding the establishment of energy } \\
\text { KPIs. }\end{array}$ & [39] \\
\hline
\end{tabular}

Looking at the literature, it is observed that improved energy management addresses multiple issues. More importantly, the industries are eventually benefitting the benefits stemming from the adoption of energy management practices [23]. Nonetheless, most of the case studies or comprehensive ones are representing the developed economies. There are very few studies that exemplify energy management comprehensively for the developing economies. Therefore, it is significantly necessary to explore the 
research gap in this area considering the fact of growing energy consumption and economic development of those countries.

\subsection{Taxonomy of Drivers and Barriers to Energy Efficiency}

Since the inception of industrial energy management practices, multiple studies have been conducted to identify and characterise the drivers and barriers to industrial energy efficiency. Furthermore, it is of utmost importance that more efficient and innovative ways for the assessment of barriers and drivers are available so that the policymakers and other concern stakeholders can work together to adopt and implement the required energy-efficient measures (EEMs) [16].

After reviewing a wide range of literature, it is found that the number of recent studies, highlighting the barriers to energy management outweighs the number of works that deal with the recent categorisation of drivers. Several works have studied the barriers to industrial energy management from the theoretical perspectives [40] as well as through different empirical investigations covering SMEs [13], and energy intensive industries [26]. These studies ensure the presence of different types of barriers, and these barriers do create various hindrances in the application of proper EEMs within the enterprises [41]. Furthermore, it is also clear from these studies that firm characteristics like firm size and sector affect the barriers to the implementation of the EEMs [42]. Table 2 comprises different barriers identified by [40] that have been considered in this study.

Table 2. Barriers of energy efficiency based on empirical investigation [40]

\begin{tabular}{|l|l|l|}
\hline Notation & \multicolumn{1}{|c|}{ Barrier } & \multicolumn{1}{c|}{ Category } \\
\hline B 1 & Inadequate support from preeminent administration & Organisation \\
\hline B 2 & Bureaucratic intricacy & Government/Policy \\
\hline B 3 & Insufficient data about energy expenditure allotment & Market/information \\
\hline B 4 & Technical ambiguity & Competence \\
\hline B 5 & Inadequate technical experts & Organisation \& competency \\
\hline B 6 & Confined impact on energy management scheme & Behavioural \\
\hline B 7 & Insubstantial attention from concern government & Government \\
\hline B 8 & Lack of staff consciousness & Awareness/ behavioural \\
\hline B 9 & Complex synodical issues & Organisation \\
\hline B 10 & Insufficient data on energy efficiency options & Information \\
\hline B 11 & Imprecise fiscal code & Economic \\
\hline B 12 & Insufficient capital expense & Economic \\
\hline B 13 & Vulnerability in energy framework (prices, slow rate of & Economic \\
& return) & \\
\hline B 14 & Poor research and development & Organisation \& competency \\
\hline B 15 & Other preferences for capital venture & Economic \\
\hline B 16 & Non visibility of demonstrated technology & Technical \\
\hline B 17 & Inadequate financial incentives & Economic \\
\hline B 18 & Complication in inter-divisional collaboration & Organisation \\
\hline B 19 & Ambiguity about latent costs & Economic \\
\hline B 20 & Time constraint or other obligatory work & Behavioural \\
\hline B 21 & Absence of competent managerial measures & Organisation \& competency \\
\hline
\end{tabular}

On the contrary, a limited number of resources are available in exploring the drivers which facilitate the energy efficiency practice. Few contributions (e.g. see [21], [43]-[45]) have been made in classifying these drivers and their impact in the decision-making practice. In [45], Johansson et al. categorised the driving forces of energy efficiency in four categories: organisational, financial, informational and external. Authors of [42] tabulated some of the recent empirical studies to industrial energy efficiency. As for the taxonomy of the drivers to industrial energy efficiency, the issues are 
discussed by Thollander et al. focusing Swedish industry [15], Schulze et al. [24], Ates et al. focusing Turkish industry [29], and Thollander \& Ottosson featuring paper and pulp industry [46]. Table 3 lists the drivers and their categorisation that are considered in our study.

Table 3. Drivers based on empirical investigations (inspired from previous studies)

\begin{tabular}{|l|l|l|}
\hline \multicolumn{1}{|c|}{ Notation } & \multicolumn{1}{c|}{ Driver } & \multicolumn{1}{c|}{ Category } \\
\hline D 1 & Energy blueprint & Organisation/ regulatory \\
\hline D 2 & Cost saving due to less end usage of energy & Economic \\
\hline D 3 & Rules and regulations & Policy \\
\hline D 4 & Ambitious individuals & Organisation \& competency \\
\hline D 5 & Arrangement for Energy Management & Organisation \\
\hline D 6 & Subsidies for energy efficiency schemes & Economic \\
\hline D 7 & Viable reduction in carbon emissions & Social/awareness/behavioural \\
\hline D 8 & Energy audit endowment & Economic \\
\hline D 9 & Suitable loan for investment with energy management & Economic \\
\hline D 10 & Assurance from preeminent management & Organisation \\
\hline D 11 & Organisational involvement in information and support & Organisation \\
\hline D 12 & Environmental benefits (other than CO $_{2}$ reduction) & Social/awareness/behavioural \\
\hline D 13 & Owner's requirement & Organisation \\
\hline D 14 & Risk posed by ever increasing price of energy & Market \\
\hline D 15 & Global competition & Market \\
\hline D 16 & Long standing accords with immunity of taxes & Economic \\
\hline D 17 & Assistance from energy professionals & Technical \\
\hline D 18 & $\begin{array}{l}\text { Pressure posed by Non Governments Organisations and } \\
\text { clients }\end{array}$ & Social/awareness/behavioural \\
\hline D 19 & Consultancy provided local jurisdiction & Competency \\
\hline D 20 & System of Green Certification & Social/awareness/behavioural \\
\hline D 21 & Taxes \& Tariffs & Economic \\
\hline D 22 & Acquaintances within the energy sector & Market \\
\hline D 23 & External investment & Economic \\
\hline
\end{tabular}

Notably, most of the studies focusing drivers and barriers to industrial energy efficiency are conducted in the context of a developed economy. Unfortunately, the same cannot be said for the developing countries, specifically for Bangladesh. In recent time, only two studies featuring steel industry [2], and textile industry [3] have been conducted by Hasan et al. to explore the drivers and barriers towards industrial energy efficiency. Nonetheless, the studies are preliminary and require in-depth exploration. Therefore, a significant research gap exists in the energy management field in Bangladesh. Considering the present industrial growth of the country [47], certainly, there is a high demand to explore the energy management domain comprehensively.

\subsection{Energy Service Companies (ESCOs)}

The concept of Energy Services Companies (ESCOs) was developed in the time of 1980s in North America. However, the actions and implementations related to ESCOs began at the close to 1980s and beginning of 1990s [48]. The idea of ESCO started to receive attention due to energy predicament resulting from the oil price hike in the early 1970s [49].

Energy service companies (ESCOs) provide private services for efficient energy management by providing sufficient planning and equipment. The services offered by ESCOs include energy savings, energy efficiency and energy conversion [50]. Besides, the ESCOs also provide multiples types of services that include energy financing, energy and technical consultancy and assistance, equipment installation service along with operation and maintenance. In addition, energy service up-gradation, including monitoring as well as measurement are also incorporated in the features of ESCOs [51]. The 
ESCO model can be categorised based on their focusing feature (e.g. business or financing). Among the models, the commonly applied business models are "shared savings" and "guaranteed savings" [49]. However, the other models incorporate outsourcing of energy management which are found as significantly prevalent in ESCOs based in the European Union [52].

ESCO industries had insured significant energy savings in many developed and developing countries [50]. Notably, the financing mechanism of ESCOs in the energy improvement sector had successfully delivered in the United States of America, Austria, Japan, South Korea [47] and several European countries [52]. As remittance of ESCO is related to the output achieved by energy savings, unlike conventional firms, countries like Japan and United States of America have carried much research focusing on aspects of ESCO industries [54]. The surge in energy consumption has made the necessity of ESCO momentous, especially in energy-intensive sectors. However, the outcome of [49] suggests that the development of ESCO is dependent on the country's affluence.

However, many developing economies are still reluctant to facilitate of ESCOs. There are few significant studies to find out the hindrances to consult ESCOs in the developing economies. In China, the awareness of energy-saving potential, including inadequate support mechanism, is identified as a substantial barrier [55]. Public awareness, the credibility of ESCOs, and lack of knowledge regarding ESCOs are identified as significant barriers in India [55]. Funding public awareness is found as the foremost barrier in Africa (Egypt, South Africa and Kenya) [48]. In the Philippines, the lack of ESCO business concept is found as a significant barrier. However, in Brazil, energy efficiency marketing is identified as a significant barrier to consult ESCO [48].

It is unblemished by the ephemeral synopsis of the literature presented that energy management is significantly essential to imply energy efficiency in the industries. Very few studies are conducted until now, incorporating the comprehensive inquisition concerning energy management practices in the energy-intensive industrial sector. Based on the circumstances, we have focused on finding the unexplored factors of energy management affecting the industrial energy efficiency comprehensively. Hence, in the next section, we present the methods and steps to explore the factors which are significantly affecting energy management in the industries.

\section{Methodology}

This study was carried out through multiple case study investigation format based on Yin's work [56]. A case study is effective when it addresses the question of 'how' and 'why'. In this format, the researchers do not have any authority on the events [57]. The information was compiled, also thanks to the support of questionnaires in this study, to standardize the sequence questions were asked [58]. In context, the study is conducted in three steps mainly. An intensive literature review \& practical cases were studied in the beginning to capitulate on state of the art about energy management and practices in the industries. Later on, the predesigned questionnaire was sent to the stakeholders working at different energy-intensive industries in Bangladesh. A total of thirty-six respondents' feedbacks have been analysed, and data reliability was checked by the Cronbach's alpha test. Finally, the findings that include energy management scenario, drivers and barriers to energy efficiency, energy efficiency potential, and barriers to energy services companies (ESCOs) are presented.

The detailed methods are discussed below and presented in Figure 2. 


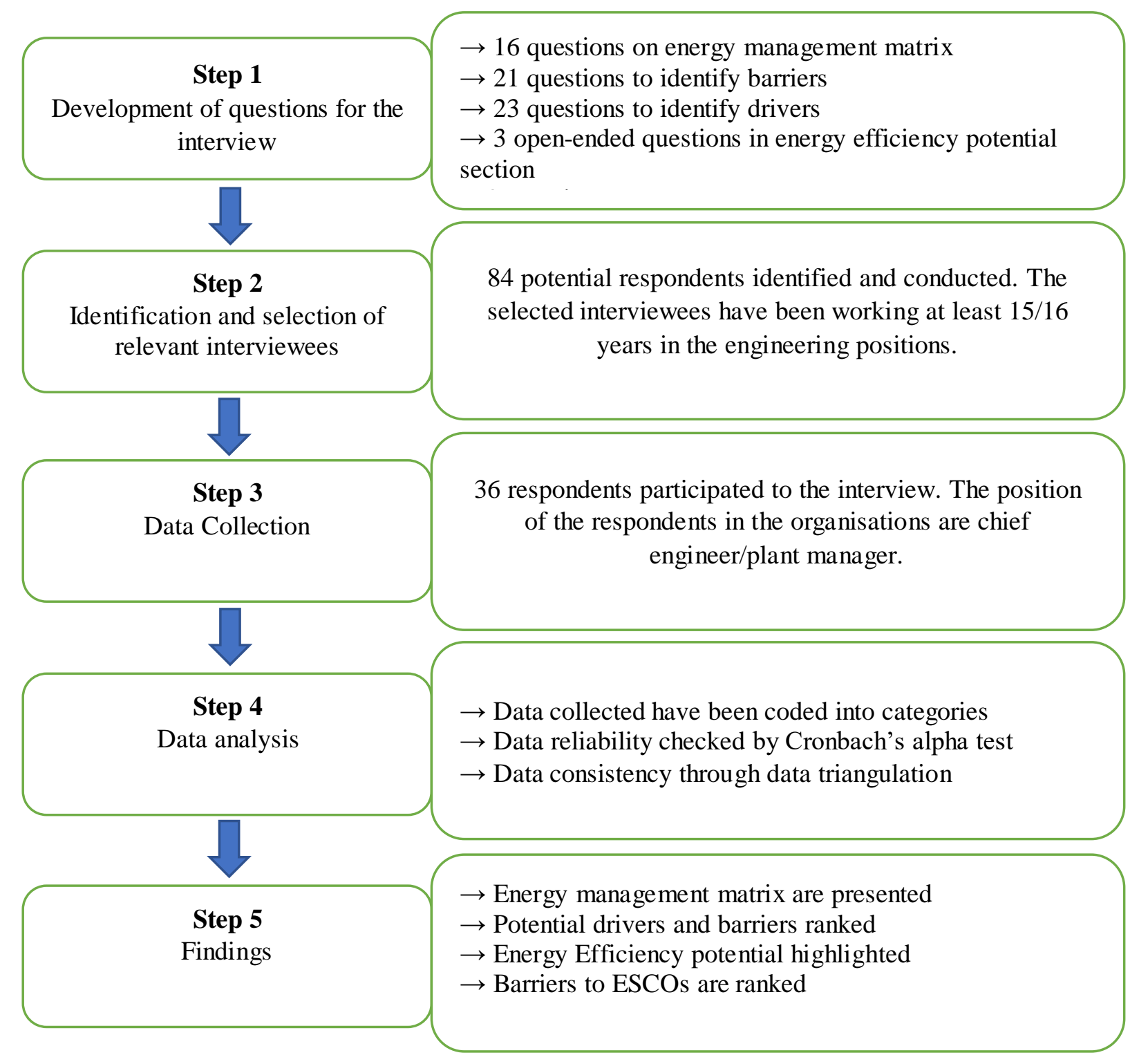

Figure 2. Chronological steps of the methodology of this research

\subsection{Interview}

As outlined in the introduction, so far, only a handful of studies have been conducted comprehensively evolving in the theme of energy management at energy-intensive industries to the best of authors' knowledge. Therefore, this study has considered energy management in a comprehensive way incorporating multiple aspects associated with industrial energy management. In this context, we have designed the semi-structured interview with support of a questionnaire divided into several sections to comply with the research gap. The incorporated sections refer to energy management; challenges and motivations for energy efficiency; options for energy efficiency in the industries; energy efficiency potential; and energy service companies (ESCOs). In this study, the questionnaire was designed as a closed format other than the segment named "Energy Efficiency Potential".

In the beginning, the participants were instructed to provide basic details such as revenue, energy enduse, and the number of employees. The significant parts of the questionnaire started with energy management section. The broad categories of possible actions for improved energy efficiency were covered in the energy management section. The classifications that are considered in this segment are the "organisation", "information system", "awareness", "investment", and "policy"- a matrix 
formulated by the UK's Carbon Trust [59]. The considered categories are linked with energy measurement and ascertained from academic literature for the relevant industries. In the "organisation" section, the questions precisely focused on energy manager and associated issues. The "information system" comprised of energy audits and its frequency related questions. The promotion of energy efficiency and training issues were asked in "awareness" section. The financial issues (e.g. payback, internal rate of return, net present value, and third-party financing) have been discussed at "investment" section. Finally, the policy matters were covered in "policy" segment. Additional success factors are also inclined with the categories devised from relevant literature in this study [60]. The weighting factors considered in this study are devised from relevant literature [27] for various sub-classes while portraying the energy management matrix. The factors for the individual aspect are presented below in Table 4. However, in the "investment" section, weighting factors have been considered for the payback time only to maintain the soundness of the quantification process.

Table 4. The weighted values considered in energy management matrix

\begin{tabular}{|c|c|c|c|}
\hline Segment & Issue & Weighted value & Notation \\
\hline \multirow{3}{*}{ Policy } & $\begin{array}{l}\text { Inadequate policy/ goals are not } \\
\text { properly written }\end{array}$ & 0.25 & A 1 \\
\hline & $\begin{array}{l}\text { Long-term energy strategy (time: } 1 \text { - } \\
3 \text { years) }\end{array}$ & 0.50 & A 2 \\
\hline & $\begin{array}{l}\text { Long-term energy strategy (time: } \\
\text { more than } 3 \text { years) }\end{array}$ & 1.00 & A 3 \\
\hline \multirow{3}{*}{ Organisation } & $\begin{array}{l}\text { no energy manager or part-time } \\
\text { energy manager }\end{array}$ & 0.25 & A 4 \\
\hline & Ad-hoc basis energy manager & 0.50 & A 5 \\
\hline & Dedicated full-time energy manager & 1.00 & A 6 \\
\hline \multirow{9}{*}{$\begin{array}{l}\text { Information } \\
\text { System }\end{array}$} & Energy audits are conducted & 1.00 & A 7 \\
\hline & Frequency: Daily & 1.00 & A 8 \\
\hline & Frequency: Monthly - Weekly & 0.50 & A 9 \\
\hline & Frequency: Annually - Quarterly & 0.25 & A 10 \\
\hline & $\begin{array}{l}\text { Type of energy: Steam and hot- } \\
\text { water }\end{array}$ & 0.25 & A 11 \\
\hline & Type of energy: Fuel & 0.25 & A 12 \\
\hline & Type of energy: Electricity & 0.25 & A 13 \\
\hline & Allocation of Energy: Sub-metering & 1 & A 14 \\
\hline & Allocation of Energy: Per tonne & 0.25 & A 15 \\
\hline \multirow{3}{*}{ Awareness } & $\begin{array}{l}\text { Absence of promotional activities } \\
\text { including training on energy } \\
\text { efficiency }\end{array}$ & 0.25 & A 16 \\
\hline & $\begin{array}{l}\text { Some ad-hoc staff awareness } \\
\text { training; ne wsletters/posters }\end{array}$ & 0.50 & A 17 \\
\hline & $\begin{array}{l}\text { Regular activities on energy } \\
\text { efficiency and its marketing value }\end{array}$ & 1.00 & A 18 \\
\hline \multirow{4}{*}{ Investment } & Payback time for less than 1 year & 0.25 & A 19 \\
\hline & Payback time between 1 and 2 years & 0.50 & A 20 \\
\hline & Payback time between 2 and 3 years & 0.75 & A 21 \\
\hline & Payback time for more than 3 years & 1.00 & A 22 \\
\hline
\end{tabular}

The next section covered the queries focusing barriers to industrial energy efficiency. The questions featured factors like technical, financial, organisational, and policy restraints. However, this section also covered the future challenges posed by the competitors. The following section inquired about the drivers 
to energy efficiency. The questions representing both the barriers and drivers to energy efficiency are presented in Table 2 and Table 3. The inclusion of the questions followed similar well-established approaches in research conducted in other sectors (e.g., studies focused on steel industries [2], textile industries [3], and cement industries [61]).

The possibilities and opportunities for practicing energy efficiency were covered in the fourth section. In this part, specific questions featuring energy reduction were asked to the participants. Nonetheless, the concluding phase of the questionnaire focused on energy service companies (ESCOs). The potential barriers to ESCOs were asked in this section.

\subsection{Stakeholders for the investigation}

The questionnaire was sent to personnel who have a great deal of experience in their respective fields, such as plant managers or chief operating engineers. Notably, all the respondents considered in this study are working in the industrial sector for more than 15/16 years. As they are the key people in running the operations, their insights bring significant value to the study. The responses were considered through arithmetic means only, by a numbered Likert scale. The criterion for selecting the energyintensive industries was energy cost allocation. The companies having energy cost more than $8 \%$ of total revenue are considered as energy-intensive industries in this study. The list of industries that fulfills the criterion of this study was collected from the Bangladesh Export Processing Zone Authority.

\subsection{Data collection, analysis and findings}

Thirty-six (36) industries agreed to take part in this study out of eighty-four (84) companies. The response rate is satisfactory compared to other studies conducted at different scenarios and context. The reason behind the high response rate is an instruction from the higher authority and willingness to participate in energy management studies. In addition, the Sustainable and Renewable Energy Development Authority (SREDA), one of the controlling organisations of energy issues in Bangladesh, instructed the industries to participate in different energy studies [62]. Similar studies were conducted for textile industries [3] and non-energy intensive manufacturing industries of Bangladesh [20]. The response rate for textile industries was $40 \%$, and non-energy intensive industries were $23 \%$. The participants were instructed to rate the perceived drivers and hurdles in the scale of " 0 (Not important)" to "1 (Extremely important)". The feedback of the respondents was cross-checked later on via telephonic conversation. For the internal consistency of the study, Cronbach's Alpha parameter was used. Any value of alpha higher than 0.75 were considered as reliable [61].

Table 5. Investigation approach at a glance

\begin{tabular}{|c|c|}
\hline Topic & Remark \\
\hline No. of industries questionnaire was sent & 84 \\
\hline Total respondents & 36 \\
\hline Response rate & $43 \%$ \\
\hline Respondent's designation & Plant manager/ Chief engineer \\
\hline No. of questions asked & No \\
\hline Outsourcing option & 2 to 4 years. \\
\hline Payback criteria & Cronbach's Alpha test \\
\hline Reliability checking tool & \\
\hline
\end{tabular}

The influential issues on energy management practices are ranked and presented in the results and discussion section. The arithmetic means are considered only on the responses. Nonetheless, the discrepancies in perceptions are not taken into consideration in our study. In addition, the statistical frequency distribution has been incorporated to highlight the data analysis. In the statistical domain, the frequency table is one of the basic tools for presenting descriptive statistics and commonly 
applied into the dissemination of data [65]. The data representation in the frequency table or graphical visualisation is useful to analyse categorical data as well as screening data for data entry errors [66]. Analysis by correlation is also conducted to further explore the relation among the aspects of energy management, drivers and barriers to energy management, and barriers to energy services companies.

A similar data analysis approach had been widely adopted by previous literature in the industrial energy efficiency and energy management domains. Hasanbeigi et al. focused on the Thai industry [67] and presented the barriers to industrial energy efficiency incorporating basic statistical analysis. In another study, Rohdin et al. investigated the barriers and drivers within the Swedish foundry industry [8] with a similar approach. Likewise, Trianni et al. explored barriers to industrial energy efficiency in European foundries [17]. Johansson studied the Swedish steel industry [68], whereas Backman focused on the SMEs [69].

\section{Energy management practices}

There are standards and guidebooks in the industry and academia addressing the energy management. However, majority of them are covering only the technical and buildings perspectives. The ISO 50001 is a significant standard, though, it covers the energy management issues in a generic way. Comprehensive guidebooks on industrial energy management featuring technical perspectives as well as policy, managerial, and other issues are still lacking.

In this study, we have used Energy Management Matrix by Carbon Trust to maintain the consistency with current energy management standards. The energy management matrix provides significant insights about any organisation's current position with respect to energy management [27]. The matrix was complemented with notable success factors towards energy management practices as like energy strategy, top management support, sub-metering issues and so forth. The companies were assigned points for each considered factor (e.g. policy, organisation, information systems, awareness, and investment). By doing so, we receive more granular understanding about actual situation of energy management in the energy intensive industries of Bangladesh.

Here, we have presented the total sample results in Section 4.1, also analysing the frequencies of responses. In addition, we have performed a preliminary analysis of the correlations presented in Section 4.2 to further explore the energy management and associated aspects.

\subsection{Analysis of energy management matrix by average score and frequency of responses}

Figure 3 presents the energy management matrix along with frequency of responses and average value. By analysing the result, we can observe several interesting findings. Firstly, energy audits (average of 0.78) represent the most implemented practice, followed by energy monitoring (frequency daily to annually/quarterly), all following under the category of "information systems". However, the audits are conducted by in-house stakeholders in most cases. Notably, to overcome the energy efficiency gap, governmental industrial energy audit programs subsidising the enterprises are the most common policy [70]. We find in this study that, a gap still exists in this sector at Bangladesh between the governmental initiatives and industrial energy audits. In addition, a comprehensive energy audit on a detailed level is to be preferred in the industries to bring additional benefits as well as to encourage the industries to work continuously with energy efficiency by incorporating it into the organisation's management. The energy service companies (ESCOs) can contribute significantly into the energy audit program. We find that most of the companies are unaware about energy service companies and their offerings. Therefore, we recommend to incorporate the ESCOs at the industries to best leverage not only to the energy audits but also energy management in a broader umbrella. 


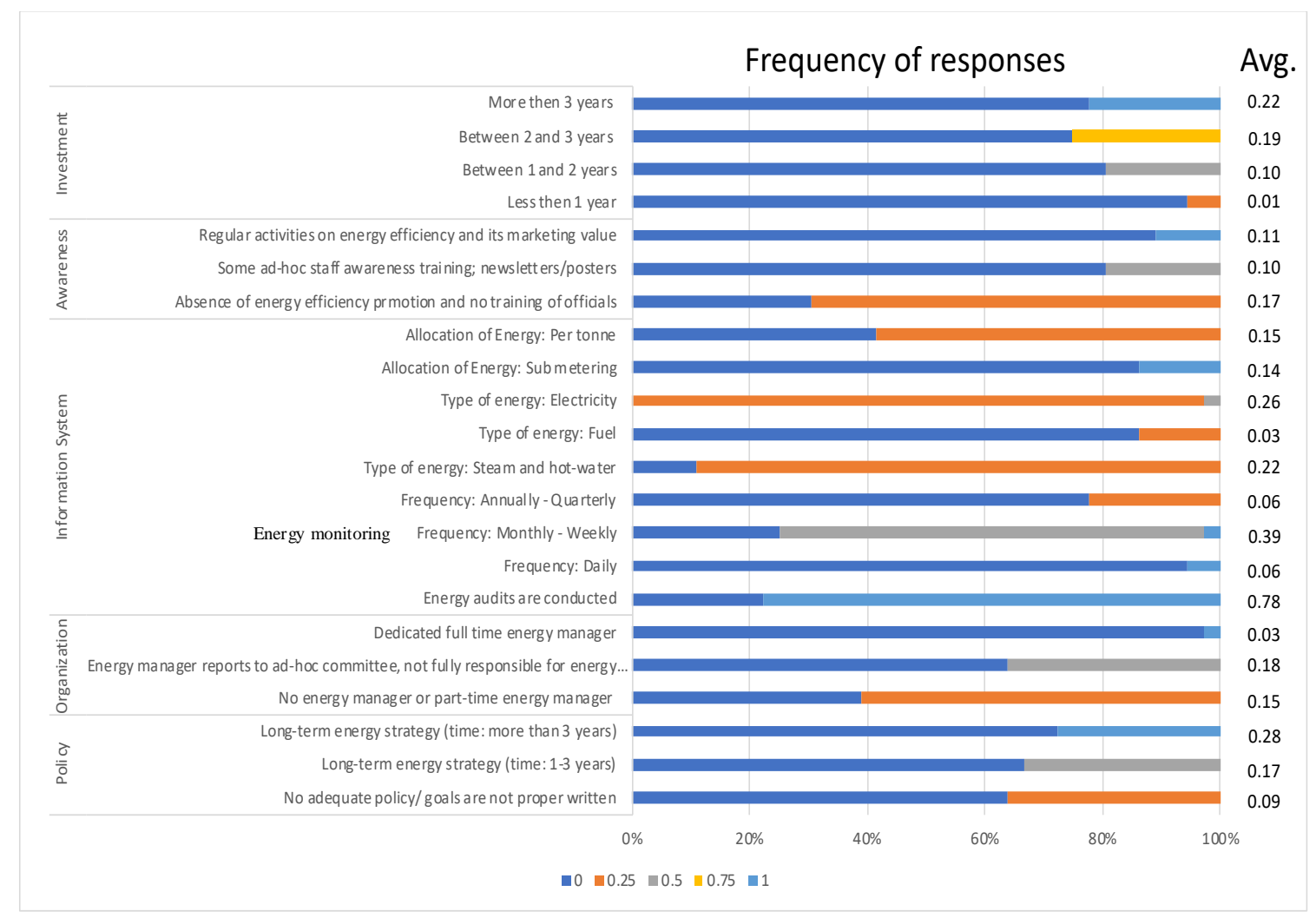

Figure 3: Energy management matrix, with frequency of responses and average for the whole sample

Secondly, there are only a few practices with values higher or closer to 0.5 , indicating that the vast majority of the companies barely implement the energy management practices proposed. In the industrial energy efficiency domain, two significant studies conducted by Backlund et al. [31], and Palm $\&$ Thollander [71], have distinctly stated that it is only possible to maximise the energy efficiency with the combined approach of energy efficient technical measures along with energy management \& its practices, given that the sole diffusion of energy efficient technologies is not sufficient to harness the full energy efficiency features. Considering the recent industrial development [47], it seems urgent for a developing economy like Bangladesh to focus on industrial energy management comprehensively in order to ensure efficiency and sustainability at the industries.

Thirdly, we find that almost entire of the sampled industries do not integrate full time energy manager into the organisational structure (only 1 out of 36 does). The energy manager should be considered as a dedicated post in the organisational structure to be responsible for monitoring and analysing energy as well as resource consumption so as to develop, get approved and implement consistent energy efficiency projects. However, today's energy manager is a multifaceted character with modernised knowledge and expertise linking multiple fields beyond energy; including technology, environment, people, finance, personal \& enterprise communication, and information technologies [72]. The integration of energy manager into the organisational structure with higher power could significantly contribute towards increasing energy efficiency and sustainability in a company. In this regard, the absence of energy manager is identified as one of the major barriers to comply energy efficiency measures in industries [73]. Moreover, a comprehensive energy management program incorporating energy manager along with other energy management practices is capable to bring a significant return on investment as well as improvement in terms of cost competitiveness, as earlier research shows [74]. Therefore, the inclusion of an energy manager becomes even more important for the energy intensive industries where a significant portion of overhead costs are attributed to energy cost. 
Currently, in the companies that took part in the study, either electrical or mechanical engineers are responsible for managing the energy issues (not comprehensively) in their plants. Though the concept of energy manager in the industries is relatively new in many countries, the necessity of an efficient and dedicated person to deal with energy issues have always been realised. In this regard, it thus seems important for concerned stakeholders (e.g. owners, policy-makers) to consider integrating dedicated energy managers in the industries.

Fourthly, we can see that only a limited number of companies (10 out of 36) have implemented a long term energy strategy with an investment perspective longer than 3 years. This result is particularly critical as it may jeopardise the success of many valuable initiatives for improving energy efficiency, suggesting that, at least from the investigated sample in a developing economy, companies are far from considering energy efficiency investments with a strategic perspective, as suggested by Cooremans [75].

Further, we have analysed the frequency of responses by individual category (e.g. awareness, organisation, investment, policy, and information system), as presented and discussed below.

\section{Awareness}

In the studied organisations, the segment that has very low value in frequency of responses and requires utmost improvement is "awareness" related to energy management. The concerned stakeholders at all levels are needed to be taught about energy management practices, including the capacity of intensifying the production. By looking at Figure 3, it can be seen that promotional activities are the most visible gap that needs to be addressed immediately. However, the regular activities on energy efficiency \& its associated value also demand the attention to be given adequately.

\section{Organisation}

The organisations need to consider energy efficiency conjecture, and thus the integration of dedicated energy engineer or energy manager into the organisational hierarchy is much crucial. Looking at Figure 3 , it can be observed that the industries suffer most due to lack of full-time energy manager.

Considering the present industrial growth in Bangladesh, maintaining some standardisations specially the ISO 50001 seems one of the best ways to deal with energy management issues. Looking at the result, it can be seen that a significant gap exists in the energy management field comprising to "awareness" and "organisation". The ISO 50001 becomes even more important when we tend to focus energy management from organisational perspectives. The ISO 50001 is expected to enable all the features and tools for the industries by which the local industries can examine their processes and systems related to energy performance [69], efficiency and intensity [70]. In addition, by executing the standard ISO 50001, the organisations will have the options to appliance a holistic energy management system that includes energy targets, objectives and policy [78]. The features of the standard ISO $50001 \mathrm{can}$ also be modified based on the organisation's requirement [79].

\section{Investment}

In the "investment" category of energy management matrix, it is found that 26 industries use payback time to calculate the profit, showing an overall lack of knowledge over the main techniques for conducting a proper investment analysis, which is however diffused also in other developed economies as previous research notes [80]. In fact, only seven industries calculate the net present value (NPV) as well as the internal rate of return (IRR). In doing this, only eight industries are found that consider investments with payback times longer than three years. Furthermore, it is found that energy-intensive industries are mostly short-term profit-oriented and focus on other prioritised financial investments. Therefore, the share of financial investment at large industries related to energy management needs to be increased. 


\section{Policy}

The policy has a great significance when it comes to the issue of industrial energy efficiency measures implementation. By looking at Figure 3, it is observed that there remains a certain gap in the policy framework in the industries of Bangladesh. Most of the industries suffer due to long term energy strategy. Therefore, standardised policy framework should be established in a long term basis from the government as well as other concerned stakeholders, to implement industrial energy management system properly.

Nonetheless, the inception of policies for energy management, efficiency and auditing in Bangladesh was in 2015, based on previous energy policies. The National Energy Policy of 2004, was the first precursor in this context, where its preceding policies were concerned with deficiency of systematic development in the generation, distribution and transmission of energy, as well as data collection, utilisation and research of potential energy sources. Furthermore, the Sixth National Five-Year Plan (2011-2015) paid more attention to extenuating the mismatch between the supply and demand of electrical energy by importing energy from neighboring countries and Public-Private Partnership (PPP). This particular policy implicitly promoted energy efficiency through several key measures to support energy-efficient usage, such as fuel diversification, scheduling of demand, price revision, lowered taxes for importing power plant equipment, distribution of energy-efficient CFL bulbs, and so on, and made its place in the Seventh Five-Year Plan (2016-2020) of Bangladesh, as well. USAID (an American organisation) completed a country-wide program in 2012, which was titled "Catalysing the Energy Efficiency in Bangladesh" targeting the increase of energy efficiency in the industries [81].

However, a comprehensive approach is still lacking to address the standardized policy framework that incorporates specific focus on industrial energy management. The existing policies do not have clear guidelines about top management integration with energy efficiency measures, presence of energy manager, monetary fines for not complying, tiering of energy auditors, and more importantly awareness program among the employees about energy efficiency. As a result, the task of implementation becomes more challenging due to the weakened ability of enforcement [82]. According to a study conducted in Italy and the United Kingdom, even after having an effective technical policy, governments often introduce several neoclassical approaches that do not target the energy efficiency plan [83].

\section{Information System}

The provisions of energy cost through sub-metering and energy audit are essential to achieve energy management profoundly. Our findings show that 21 industries among 36 earmark their energy in terms of a tonne. However, the number of industries use sub-metering are 5. Interestingly, none of the industries allocates the energy cost in terms of the square meter or employee basis. Notably, all the industries rely on electricity for activities. Besides, there are five industries that consider natural gas as fuel. Notably, 28 industries had gone through the energy audit (not in a comprehensive manner).

\subsection{Correlation analysis of Energy Management}

A preliminary analysis of correlations has been performed to highlight some possible relationships between practices within the Energy Management Matrix. Considering the exploratory nature of the study and the limited number of investigated companies, we have limited our following comments exclusively to the strongest correlations, highlighted in Table 6 (red, "very strong" $>=0.8$; yellow, "strong" > $=0.7$ ). From this first analysis, we can see that the correlation is overall low, therefore with interviewees not seeming to link a number of possible relationships between practices in the EMM. This may mean that companies are lacking to see at the proposed practices with a (either positive or negative) synergic approach, thus with the implementation of some practices fostering (or hindering) the adoption of others. Again, this result seems to show that companies are not taking a holistic view over energy management as an integrated approach, rather implementing practices in a scattered way. 
Further, we can note that some correlations have been highlighted within the same categories. In particular:

- No energy manager or part-time energy manager with limited authority and energy manager reports to ad-hoc committee, not fully responsible for energy consumption : $(0.84)$

○ Energy Monitoring (Frequency: Monthly - Weekly) and Energy Monitoring (Frequency: Annually - Quarterly): (0.81)

$\circ$ Absence of energy efficiency promotion and no training of officials and some ad-hoc staff awareness training; newsletters/posters: (0.74)

In particular, we can observe that the lack or limited authority of an energy manager (A 4) represents a potential issue, where the energy manager also reports to the ad-hoc committee (A 5). This issue particularly has impact on barriers to energy efficiency (such as the organisational one on long decision chain, or the low rank of energy efficiency in the organisational chart), as discussed further. Furthermore, we have noted that another two practices within the information systems category present higher correlation coefficients, such as Energy Monitoring (Frequency: Monthly - Weekly, A9) and Energy Monitoring (Frequency: Annually - Quarterly, A10). Such finding may reflect the capability of some companies to scale up to higher frequency for accounting once started to implement the energy monitoring practices. Therefore, it seems to represent an interesting finding related to the lower inertia of more deeply implementing a very important set of energy management practices such as energy monitoring, which is essential for increased knowledge and decision-making. Additionally, we have observed a strong correlation between absence of promotional activities including training on energy efficiency (A 16) and some ad-hoc staff awareness including training, newsletters/ posters (A 17). The correlation seems to reflect how the staff awareness and trainings on energy efficiency measures are affected by absence of promotional activities including training on energy efficiency. 
Table 6. Total sample analysis of correlations. Significant values are represented in bold

\begin{tabular}{|c|c|c|c|c|c|c|c|c|c|c|c|c|c|c|c|c|c|c|c|c|c|c|c|}
\hline & & \multicolumn{3}{|c|}{ Policy } & \multicolumn{3}{|c|}{ Organisation } & \multicolumn{9}{|c|}{ Information System } & \multicolumn{3}{|c|}{ Awareness } & \multicolumn{4}{|c|}{ Investment } \\
\hline & & A 1 & A 2 & A 3 & A 4 & A 5 & A 6 & A 7 & A 8 & A 9 & A 10 & A 11 & A 12 & A 13 & A 14 & A 15 & A 16 & A 17 & A 18 & A 19 & A 20 & A 21 & A 22 \\
\hline \multirow{3}{*}{ Policy } & A 1 & 1.00 & 0.51 & 0.47 & 0.21 & 0.20 & 0.22 & 0.15 & 0.32 & 0.02 & 0.12 & 0.27 & 0.13 & 0.13 & 0.13 & 0.07 & 0.25 & 0.07 & 0.29 & 0.07 & 0.08 & 0.03 & 0.26 \\
\hline & A 2 & - & 1.00 & 0.42 & 0.44 & 0.36 & 0.11 & 0.11 & 0.16 & 0.02 & 0.14 & 0.07 & 0.12 & 0.11 & 0.03 & 0.04 & 0.33 & 0.20 & 0.24 & 0.06 & 0.19 & 0.03 & 0.11 \\
\hline & A 3 & - & - & 1.00 & 0.18 & 0.08 & 0.10 & 0.03 & 0.15 & 0.15 & 0.12 & 0.37 & 0.29 & 0.27 & 0.11 & 0.02 & 0.13 & 0.17 & 0.02 & 0.15 & 0.15 & 0.07 & 0.27 \\
\hline \multirow{3}{*}{ Organisation } & A 4 & - & - & - & 1.00 & 0.84 & 0.19 & 0.19 & 0.22 & 0.24 & 0.33 & 0.32 & 0.13 & 0.15 & 0.36 & 0.30 & 0.11 & 0.02 & 0.14 & 0.03 & 0.16 & 0.26 & 0.07 \\
\hline & A 5 & - & - & - & - & 1.00 & 0.13 & 0.29 & 0.18 & 0.30 & 0.29 & 0.27 & 0.03 & 0.13 & 0.30 & 0.28 & 0.12 & 0.08 & 0.08 & 0.07 & 0.08 & 0.23 & 0.26 \\
\hline & A 6 & - & - & - & - & - & 1.00 & 0.09 & 0.04 & 0.25 & 0.32 & 0.06 & 0.07 & 0.03 & 0.07 & 0.20 & 0.25 & 0.34 & 0.06 & 0.04 & 0.08 & 0.29 & 0.09 \\
\hline \multirow{9}{*}{$\begin{array}{l}\text { Information } \\
\text { System }\end{array}$} & A 7 & - & - & - & - & - & - & 1.00 & 0.13 & 0.16 & 0.13 & 0.02 & 0.02 & 0.09 & 0.02 & 0.18 & 0.37 & 0.09 & 0.66 & 0.13 & 0.08 & 0.15 & 0.04 \\
\hline & A 8 & - & - & - & - & - & - & - & 1.00 & 0.15 & 0.13 & 0.09 & 0.25 & 0.04 & 0.10 & 0.29 & 0.16 & 0.12 & 0.09 & 0.06 & 0.12 & 0.14 & 0.13 \\
\hline & A9 & - & - & - & - & - & - & - & - & 1.00 & 0.81 & 0.05 & 0.02 & 0.05 & 0.27 & 0.05 & 0.09 & 0.11 & 0.27 & 0.15 & 0.40 & 0.41 & 0.16 \\
\hline & A 10 & - & - & - & - & - & - & - & - & - & 1.00 & 0.02 & 0.02 & 0.09 & 0.02 & 0.09 & 0.06 & 0.08 & 0.19 & 0.16 & 0.26 & 0.46 & 0.13 \\
\hline & A 11 & - & - & - & - & - & - & - & - & - & - & 1.00 & 0.14 & 0.48 & 0.62 & 0.24 & 0.34 & 0.27 & 0.16 & 0.09 & 0.05 & 0.20 & 0.45 \\
\hline & A 12 & - & - & - & - & - & - & - & - & - & - & - & 1.00 & 0.07 & 0.16 & 0.01 & 0.09 & 0.01 & 0.14 & 0.10 & 0.20 & 0.14 & 0.17 \\
\hline & A 13 & - & - & - & - & - & - & - & - & - & - & - & - & 1.00 & 0.42 & 0.20 & 0.25 & 0.34 & 0.06 & 0.04 & 0.08 & 0.10 & 0.32 \\
\hline & A 14 & - & - & - & - & - & - & - & - & - & - & - & - & - & 1.00 & 0.48 & 0.26 & 0.21 & 0.11 & 0.10 & 0.41 & 0.23 & 0.17 \\
\hline & A 15 & - & - & - & - & - & - & - & - & - & - & - & - & - & - & 1.00 & 0.30 & 0.44 & 0.12 & 0.29 & 0.15 & 0.10 & 0.05 \\
\hline \multirow{3}{*}{ Awareness } & A 16 & - & - & - & - & - & - & - & - & - & - & - & - & - & - & - & 1.00 & 0.74 & 0.53 & 0.16 & 0.02 & 0.03 & 0.23 \\
\hline & A 17 & - & - & - & - & - & - & - & - & - & - & - & - & - & - & - & - & 1.00 & 0.17 & 0.12 & 0.06 & 0.04 & 0.24 \\
\hline & A 18 & - & - & - & - & - & - & - & - & - & - & - & - & - & - & - & - & - & 1.00 & 0.09 & 0.05 & 0.00 & 0.02 \\
\hline \multirow{4}{*}{ Investment } & A 19 & - & - & - & - & - & - & - & - & - & - & - & - & - & - & - & - & - & - & 1.00 & 0.12 & 0.14 & 0.13 \\
\hline & A 20 & - & - & - & - & - & - & - & - & - & - & - & - & - & - & - & - & - & - & - & 1.00 & 0.28 & 0.26 \\
\hline & A 21 & - & - & - & - & - & - & - & - & - & - & - & - & - & - & - & - & - & - & - & - & 1.00 & 0.31 \\
\hline & A 22 & - & - & - & - & - & - & - & - & - & - & - & - & - & - & - & - & - & - & - & - & - & 1.00 \\
\hline
\end{tabular}




\section{Barriers to energy efficiency}

\subsection{Analysis of barriers by average score and frequency of responses}

Figure 4 reports perceived barriers to energy management initiatives, including average values and frequencies of responses. The outcomes demonstrate "Inadequate support from preeminent administration" and "Bureaucratic intricacy" as significant hindrances to energy efficiency in energy intensive industries of Bangladesh. The other noteworthy distinguished barriers were "Insufficient data about energy expenditure allotment" and "Technical ambiguity".

The high ranked barriers that have emerged, namely "Inadequate support from preeminent administration (average score: 0.90)" and "Bureaucratic intricacy (average score: 0.83 )" point out the administrative hurdles affecting the enterprises. In both cases, more than 30 out of 36 interviewees deemed those barriers at least important (34/36 and 32/36, respectively), and none of the participants marked this issue as "not important". Indeed, this expresses the significance of administration support to adopt energy efficiency measures in the industries. This is interesting as well as an unique finding considering the fact that, being a developing economy, financial constraints are not deemed as major barriers towards energy management in the energy intensive industries.

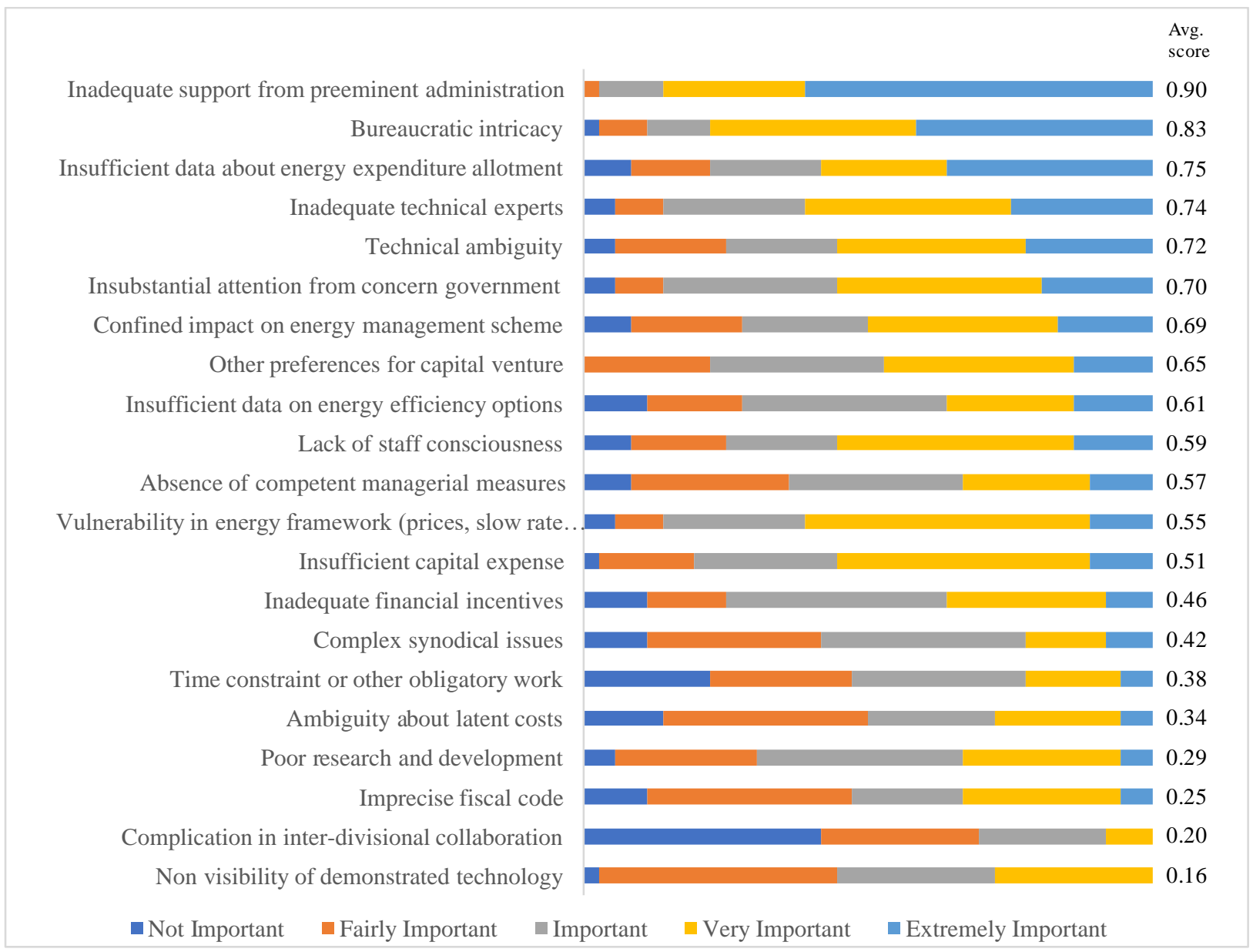

Figure 4: Perceived barriers -frequency of responses

Relating our findings to previous literature, we can note that here the bureaucratic issues are perceived with much greater relevance compared to other barriers such as financial ones and other priority of several distinct barriers for improved energy efficiency are observed, substantially differing from earlier studies, although conducted in different economies and industrial contexts. In fact, in the present study, 
inadequate financial incentives present an average score of 0.34 , with none of the respondents pointing them as extremely important. Rather, previous studies conducted in Sweden indicated that the "Access limitation of capital" and "Insufficient budget", as well as "Technological risks", as the significant hindrances for them [8]. When looking at Swedish Iron and Steel industries [27], authors show that the technical risks and limited access to capital are the most substantial obstacles. A similar study (not limited to energy-intensive industries only) was conducted in Ghana, showing the most prevalent barriers being financial; such as "Access limitation of capital", "Insufficient budget" and "Other priorities for investment" were the high ranked barriers [21].

Another study conducted in Turkey identified "Financial supports" as a significant barrier towards energy management and efficiency programs [29]. Also in comparison with previous research within textile industries [3], "Inadequate capital expenditure" was identified as the most significant barrier, which is indeed different from our present findings. In the United Kingdom, study identified other primacies for capital investment, inadequate time, inappropriate technology as the reasons for not implementing industrial energy efficiency measures [84]. Similar type of financial aspects that include poor return rate, longer payback time have been identified for the Australian firms [85]. In [41], the authors classified the barriers into several categories (e.g., behavioural, organisation technological, economic) and investigated the influence of the drivers to the barriers in a comprehensive manner, finding the economic barriers as the most influential. Another previous study [16] conducted for the Dutch industries shows that the enterprises are in agreement about the most important barriers, as well as about underlying mechanisms. Interestingly, study conducted in India, another emerging economy, identified financial barrier towards industrial energy efficiency measures [86].

Furthermore, our interviewees highlighted the lack of adequate data about energy expenditure allotment as major barrier (average score: 0.76). Again, the relevance of this barrier does not find major confirmation in earlier literature in developing economies, whilst discussed in other developed European countries focusing SMEs [11], and foundries [12]. However, the present findings confirm earlier results from technical ambiguity observed within steel industries in Bangladesh [2] again perceived as quite relevant (average score: 0.74 ). But, we can observe many dissimilarity in the findings between steel industries and present study, where the technical ambiguity, together with uncertainty over energy prices were identified as the imperative barriers to energy efficiency measures, whilst here we have observed bureaucratic issues.

Additionally, our investigation revealed that staff awareness presents a medium relevance, with an average score of 0.65 and 23/36 enterprises deeming it as at least important. Our findings here differ from earlier literature conducted in Malaysian manufacturing firms pointing out "Commitment from higher management", "Energy awareness" and "Knowledge gap" as the prominent barriers. However, this study also emphasized concern for reducing $\mathrm{CO}_{2}$ among the stakeholders [88]. In another study focusing on cement industries [61], "Lack of staff consciousness" is identified as the most imperative barrier towards energy efficiency measures. The discrepancy of our findings compared to earlier literature could be attributed to a number of reasons, including working environment, production nature, and other contextual factors. We acknowledge that the moderating effect of some contextual variables could represent a valuable opportunity for future research.

Notably to observe that the barriers of low ranked (lack of time and absence of competent managerial measures, with average scores of 0.20 and 0.16 , respectively) are also referring to organisational internal framework at present relating energy management and its practices.

In a nutshell, we can observe that sampled companies tend to blame external stakeholders for not receiving adequate support, rather than highlighting major internal hurdles preventing them to more systematically implement energy management and energy efficiency initiatives. In this case, we can find confirmation in earlier literature. However, here we are limiting our analysis to the perceived 
barriers, not discussing in depth possible misalignments with real barriers, as previous research pointed out at [80].

\subsection{Correlation analysis of barriers}

By looking at the major correlations Table 7 (red, "very strong" $>=0.8$; yellow, "strong" $>=0.7$ ), we find several interesting very strong correlations, in particular:

- Insufficient data on energy expenditure allotment (B 3) and confined impact on energy manage ment scheme (B 6): (0.83)

- Insufficient data about energy expenditure allotment (B 3) and technical ambiguity (B 4): $(0.85)$

- Technical ambiguity (B 4) and inadequate technical experts (B 5): (0.81)

- Technical ambiguity (B 4) and insubstantial attention from concern government (B 7): (0.80)

- Technical ambiguity (B 4) and confined impact on energy management scheme (B 6): (0.82)

- Inadequate technical experts (B 5) and confined impact on energy management scheme (B 6): $(0.91)$

- Inadequate technical experts (B 5) and Insubstantial attention from government (B 7): (0.95)

- Inadequate technical experts (B 5) and lack of staff consciousness (B 8): (0.83)

- Confined impact on energy management scheme (B 6) and Insubstantial attention from government (B 7): (0.96)

- Insubstantial attention from government (B 7) and lack of staff consciousness (B 8): (0.91)

- Insubstantial attention from government (B 7) and complex synodical issues (B 9): (0.88)

- Lack of staff consciousness (B 8) and complex synodical issues (B 9): (0.95)

- Confined impact on energy management scheme (B 6) and lack of staff consciousness (B 8): $(0.82)$

- Confined impact on energy management scheme (B 6) and complex synodical issues (B 9): $(0.82)$

- Non visibility of demonstrated technology (B 16) and inadequate financial incentives (B 17): $(0.84)$

Acknowledging the limited size of the sample and the exploratory nature of the investigation, we opt to comment over the major trends in the correlations, suggesting that further research with enlarged sample size could deepen such preliminary considerations. By observing the correlation, we can see that insufficient data on energy expenditure allotment (B3) seems to present a strong relationship with impact of energy management scheme (B6) and technical ambiguity (B4). This seems to indicate that the lack of data on energy expenditure is effectively connected to poor decision-making into companies, with limited understanding on the impact that proper energy management would have, also related to greater difficulties in terms of perceived compatibility of technologies. One possible reason for insufficient data on energy expenditure might be the transparency issue on expenditure from management towards employee.

To corroborate out considerations over poor decision-making in industry, our exploratory investigation shows that technical ambiguity (B4) presents a strong correlation also with inadequate technical experts (B5), lack of attention from government (B7). Here, one significant finding is that the technical uncertainty is perceived greater when technical expertise is lacking. These findings find confirmation in earlier literature focused on developed countries [87] also relating such difficulties with deficit of energy expertise in the industries. Nonetheless, we observe strong impact for inadequate technical experts with lack of attention from government as well as lack of staff consciousness on energy management. Indeed, the government is pointed as a significant stakeholder to build local expertise and adopt technical modifications comprehensively in society, however not yet acknowledging the role of other potential stakeholders in offering valuable vocational training and expertise over energy management, as observed in other industrial contexts [42]. The impact of government concern becomes even more important when it comes to imply the rules and regulation into organisational process, which 
also refer to our findings presented in Table 7. Interestingly, lack of attention from government (B7) seems also connected to lack of staff consciousness (B8). This correlation again indicates the importance of governmental attention to make the staff aware on energy management issues.

However, the found correlation between confined impacts on energy management scheme (B6) with lack of staff consciousness (B8) points out to the organisational internal context. Notably, the significance of organisational context is presented in Section 4.1 and Section 4.2 elaborately. In contrast with studies conducted in the European foundries [17], lack of influence of energy manager and low priority given to energy management is also observed as possible relationship. 
Table 7. Total sample analysis of correlations. Significant values are represented in bold

\begin{tabular}{|c|c|c|c|c|c|c|c|c|c|c|c|c|c|c|c|c|c|c|c|c|c|}
\hline & B 1 & B 2 & B 3 & B 4 & B 5 & B 6 & B 7 & B 8 & B 9 & B 10 & B 11 & B 12 & B 13 & B 14 & B 15 & B 16 & B 17 & B 18 & B 19 & B 20 & B 21 \\
\hline B 1 & 1.00 & 0.70 & 0.32 & 0.23 & 0.32 & 0.29 & 0.29 & 0.28 & 0.31 & 0.25 & 0.19 & 0.21 & 0.12 & 0.09 & 0.18 & 0.09 & 0.00 & 0.02 & 0.17 & 0.21 & 0.23 \\
\hline B 2 & & 1.00 & 0.57 & 0.47 & 0.48 & 0.52 & 0.45 & 0.38 & 0.38 & 0.33 & 0.31 & 0.28 & 0.26 & 0.14 & 0.09 & 0.06 & 0.09 & 0.09 & 0.04 & 0.19 & 0.16 \\
\hline B 3 & & & 1.00 & 0.85 & 0.75 & 0.83 & 0.72 & 0.59 & 0.50 & 0.46 & 0.49 & 0.44 & 0.41 & 0.25 & 0.20 & 0.21 & 0.05 & 0.17 & 0.25 & 0.35 & 0.35 \\
\hline B 4 & & & & 1.00 & 0.81 & 0.82 & 0.80 & 0.70 & 0.63 & 0.59 & 0.57 & 0.58 & 0.59 & 0.44 & 0.41 & 0.34 & 0.20 & 0.31 & 0.24 & 0.33 & 0.30 \\
\hline B 5 & & & & & 1.00 & 0.91 & 0.95 & 0.83 & 0.75 & 0.69 & 0.61 & 0.65 & 0.61 & 0.44 & 0.37 & 0.20 & 0.01 & 0.13 & \begin{tabular}{l|l|}
0.24 \\
\end{tabular} & 0.28 & 0.30 \\
\hline B 6 & & & & & & 1.00 & 0.96 & 0.82 & 0.82 & 0.74 & 0.56 & 0.43 & 0.32 & 0.20 & 0.22 & 0.12 & 0.14 & 0.31 & 0.26 & 0.25 & 0.12 \\
\hline B 7 & & & & & & & 1.00 & 0.91 & 0.88 & 0.82 & 0.66 & 0.48 & 0.44 & 0.32 & 0.34 & 0.18 & 0.22 & 0.41 & 0.25 & 0.25 & 0.13 \\
\hline B 8 & & & & & & & & 1.00 & 0.95 & 0.86 & 0.60 & 0.37 & 0.40 & 0.33 & 0.39 & 0.17 & 0.22 & 0.38 & 0.18 & 0.31 & 0.09 \\
\hline B 9 & & & & & & & & & 1.00 & 0.86 & 0.63 & 0.44 & 0.38 & 0.28 & 0.33 & 0.15 & 0.19 & 0.31 & 0.15 & 0.25 & 0.19 \\
\hline B 10 & & & & & & & & & & 1.00 & 0.78 & 0.47 & 0.50 & 0.37 & 0.39 & 0.19 & 0.23 & 0.33 & 0.21 & 0.28 & 0.10 \\
\hline B 11 & & & & & & & & & & & 1.00 & 0.78 & 0.78 & 0.66 & 0.59 & 0.34 & 0.35 & 0.45 & 0.12 & 0.11 & 0.13 \\
\hline B 12 & & & & & & & & & & & & 1.00 & 0.84 & 0.73 & 0.65 & 0.44 & 0.36 & 0.48 & 0.10 & 0.06 & 0.19 \\
\hline B 13 & & & & & & & & & & & & & 1.00 & 0.88 & 0.76 & 0.48 & 0.46 & 0.59 & 0.14 & 0.02 & 0.04 \\
\hline B 14 & & & & & & & & & & & & & & 1.00 & 0.83 & 0.55 & 0.49 & 0.55 & 0.04 & 0.00 & 0.21 \\
\hline B 15 & & & & & & & & & & & & & & & 1.00 & 0.64 & 0.56 & 0.57 & 0.07 & 0.01 & 0.24 \\
\hline B 16 & & & & & & & & & & & & & & & & 1.00 & 0.84 & 0.66 & 0.11 & 0.07 & 0.15 \\
\hline B 17 & & & & & & & & & & & & & & & & & 1.00 & 0.77 & 0.21 & 0.24 & 0.00 \\
\hline B 18 & & & & & & & & & & & & & & & & & & 1.00 & 0.22 & 0.20 & 0.15 \\
\hline B 19 & & & & & & & & & & & & & & & & & & & 1.00 & 0.40 & 0.17 \\
\hline B 20 & & & & & & & & & & & & & & & & & & & & 1.00 & 0.40 \\
\hline B 21 & & & & & & & & & & & & & & & & & & & & & 1.00 \\
\hline
\end{tabular}




\section{Drivers for energy efficiency}

\subsection{Analysis of drivers by average score and frequency of responses}

The ranking of drivers is presented in Figure 5, representing the inclusive average scores and frequencies of responses. "Energy blueprint (average score: 0.91 )" that refers to long term energy strategy, "Cost saving due to less end usage of energy (average score: 0.85)" and "Rules and regulations (average score: 0.82 )" were recognised as the noteworthy drivers to energy efficiency in the industries. 29 out of 36 interviewees deemed energy blueprint at least very important. On the contrary, 28 interviewees considered cost saving due to less energy usage as at least very important. Notably to mention that none of the participants considered both of these aspects as not important. The other vital drivers were "Ambitious individuals", followed by "Arrangement for Energy Management".

Further, the highly ranked drivers point out three significant dimensions which are strategical, financial savings, and lastly regulatory issues. Indeed, the identified facts are very critical to drive and implement not only energy management but also many relevant issues in the broader umbrella of energy. Moreover, the findings also ascertain and emphasize multi-dimensional approaches to industrial energy management [89]. In many cases, energy management are not considered comprehensively in the industries. However, our findings point out the importance to consider multi-dimensional facts towards industrial energy management.

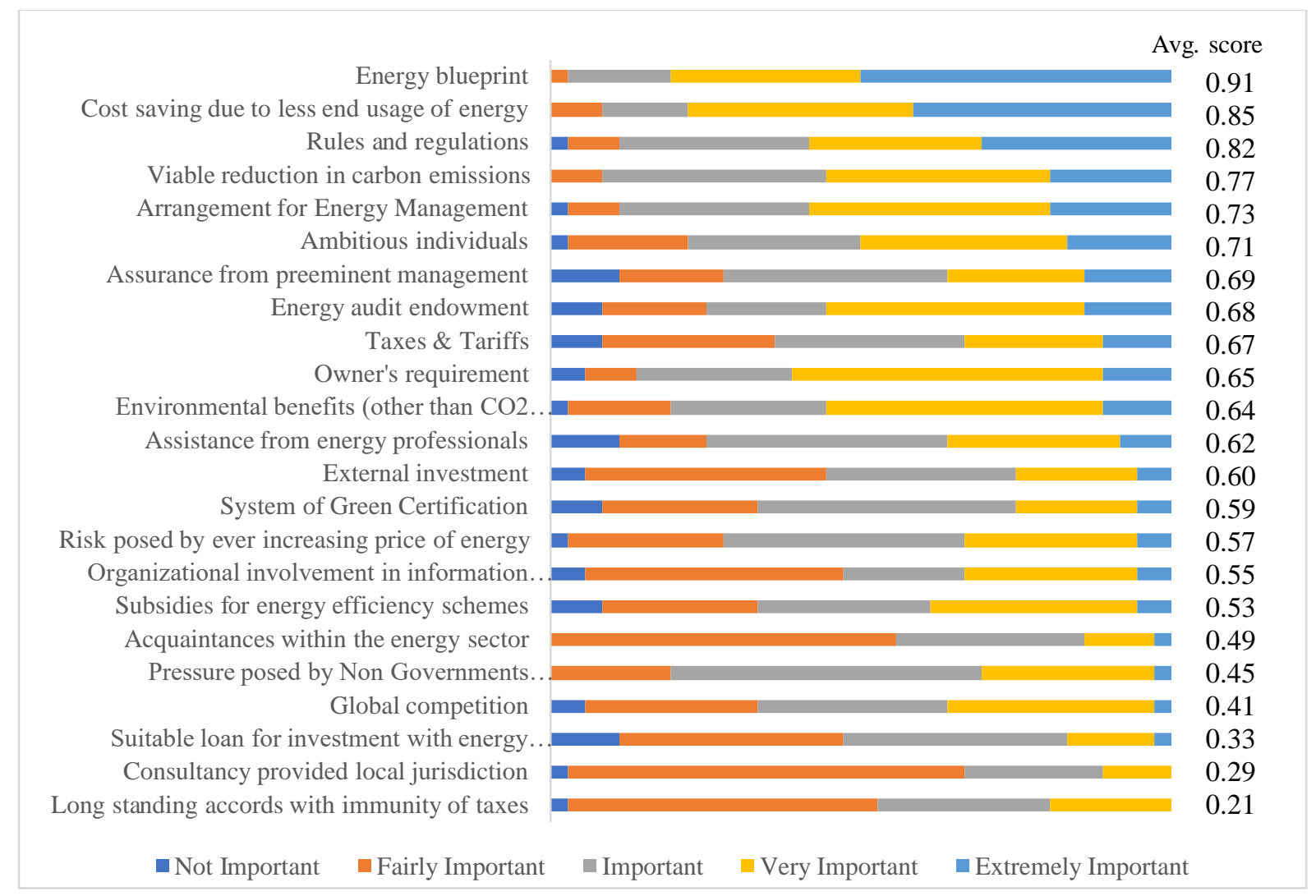

Figure 5: Perceived drivers- frequency of responses

The evidences of this study suggest that a well-designed energy blueprint and regulatory practices could accelerate the journey towards energy efficiency improvement, at the industries in Bangladesh. Furthermore, the concept of energy management being relatively new in the country, there is a clear lack of arrangement for energy management practices. 
One significant fact is observed that "acquaintances within the energy sector" and "pressure posed by non-government organisations \& clients" are not highly ranked in the list. However, none of the participants has marked these as "Not Important". Indeed, this is an interesting finding which is contextually significant and indicates the importance of external organisation's pressure, particularly the NGOs to conform sustainability in an organisation [90]. Besides, we can observe that none of the participants considers the "loan standing accords with immunity of taxes" as extremely important.

In accordance with our findings, previous studies also demonstrated the significance of energy strategy to energy efficiency measures at the industries. Cagno et al. pointed out energy strategy as one of the most important drivers to energy efficiency in the study featuring the Dutch metalworking industry [16]. In a previous study focused at the Swedish industries, energy efficiency policy program is also identified as a significant driver to energy efficiency initiatives [91]. Paramonova et al. discussed the importance of energy policy in the study featuring electricity intensive industries [92]. However, in previous research featuring Swedish foundry industry [8], the presence of ambitious people, as well as long-term strategic energy policy are the most effective means of improved energy management. In earlier study conducted in Ghana, "Lowered cost for lowered energy usage" emerges as the highest perceived driver [21]. In Thailand's manufacturing industry, the reduced production cost was identified as the highest-ranked driver [67]. The study conducted by De Groot et al. [44] focused on the Dutch industries have identified the financial savings due to less energy usage and the implementation of policies such as subsidies and fiscal arrangements as major driving forces toward the adoption of energy- efficient technologies in the industries. The economic feature, precisely, "Cost reduction from lower energy use" were pointed out as the most important driver in Swedish paper and pulp industry [19]. However, in the Italian manufacturing industries, importance of allowances as well as energy interventions financing are identified as significant drivers [43]. The study conducted in another Asian country such as Korea also reflects the financial issues - specifically cost savings - as the major driver towards energy efficiency management [93]. Interestingly to observe that most of the drivers are financial in nature irrespective of industry type. A possible explanation for this similarity is the business and profit driven nature of the industries irrespective of geographical locations.

\subsection{Correlation analysis of drivers}

By preliminarily looking at the correlations in Table 8 (red, "very strong" $>=0.8$; yellow, "strong" $>=0.7$ ), we can see that:

- Overall low correlation

- A few correlations within the same categories. In particular:

- Arrangement for Energy Management (D 5) with subsidies for energy efficiency schemes (D 6): (0.99)

- Subsidies for energy efficiency schemes (D 6) with assurance from preeminent management (D 10): (0.71)

- Energy audit endowment (D 8) with Assurance from preeminent management (D 10): $(0.72)$

- Viable reduction in carbon emissions (D 7) with environmental benefits (other than $\mathrm{CO}_{2}$ reduction) (D 12): (0.71)

- Long standing accords with immunity of taxes (D 16) with Assistance from energy professionals (D 17): (0.75)

We can see by observing the major trends in correlation matrix that the arrangement for energy management (D5) seems to represent a potential impact on energy efficiency schemes in the industries (D6). This indicates that energy efficiency related activities may be increased if there is adequate structured process and supporting mechanism. The finding is also confirmed in earlier literature [94] focused on energy management in production system. 
In contrast, subsidies for energy efficiency schemes (D6) may have potential impact with assurance from management (D10), which also indicates the impact of support mechanism within organisational framework to promote energy efficiency measures. Nonetheless, we find a high correlation coefficient between carbon emission reductions (D7) with environmental benefits (D12), which is reasonable by considering the multiple benefits stemming from the adoption of energy efficiency solutions [95]. Moreover, the correlation between long standing accords with immunity of taxes (D16) and assistance from energy professional (D17) seems to reflect the beneficial financial benefits related to technical expertise able to support companies in analysing the best energy efficiency solutions. 
Table 8. Total sample analysis of correlations. Significant values are represented in bold

\begin{tabular}{|c|c|c|c|c|c|c|c|c|c|c|c|c|c|c|c|c|c|c|c|c|c|c|c|}
\hline & D 1 & D 2 & D 3 & D 4 & D 5 & D 6 & D 7 & D 8 & D 9 & D 10 & D 11 & D 12 & D 13 & D 14 & D 15 & D 16 & D 17 & D 18 & D 19 & D 20 & D 21 & D 22 & D 23 \\
\hline D 1 & 1.00 & 0.40 & 0.17 & 0.00 & 0.25 & 0.26 & 0.29 & 0.24 & 0.14 & 0.31 & 0.01 & 0.29 & 0.31 & 0.27 & 0.03 & 0.18 & 0.19 & 0.02 & 0.14 & 0.13 & 0.13 & 0.01 & 0.25 \\
\hline D 2 & & 1.00 & 0.40 & 0.22 & 0.35 & 0.37 & 0.58 & 0.51 & 0.48 & 0.29 & 0.08 & 0.36 & 0.23 & 0.26 & 0.07 & 0.29 & 0.31 & 0.03 & 0.03 & 0.00 & 0.01 & 0.15 & 0.19 \\
\hline D 3 & & & 1.00 & 0.53 & 0.13 & 0.29 & 0.12 & 0.10 & 0.19 & 0.26 & 0.13 & 0.03 & 0.03 & 0.05 & 0.02 & 0.14 & 0.11 & 0.10 & 0.07 & 0.06 & 0.22 & 0.38 & 0.01 \\
\hline D 4 & & & & 1.00 & 0.60 & 0.64 & 0.51 & 0.53 & 0.34 & 0.53 & 0.34 & 0.28 & 0.11 & 0.05 & 0.19 & 0.16 & 0.33 & 0.12 & 0.28 & 0.23 & 0.00 & 0.09 & 0.21 \\
\hline D 5 & & & & & 1.00 & 0.99 & 0.64 & 0.63 & 0.48 & 0.69 & 0.46 & 0.66 & 0.33 & 0.43 & 0.46 & 0.65 & 0.71 & 0.47 & 0.53 & 0.39 & 0.30 & 0.22 & 0.36 \\
\hline D 6 & & & & & & 1.00 & 0.69 & 0.62 & 0.46 & 0.71 & 0.46 & 0.64 & 0.29 & 0.37 & 0.47 & 0.65 & 0.72 & 0.46 & 0.53 & 0.42 & 0.32 & 0.20 & 0.31 \\
\hline D 7 & & & & & & & 1.00 & 0.58 & 0.62 & 0.69 & 0.51 & 0.71 & 0.39 & 0.47 & 0.36 & 0.57 & 0.50 & 0.21 & 0.32 & 0.20 & 0.13 & 0.05 & 0.25 \\
\hline D 8 & & & & & & & & 1.00 & 0.54 & 0.72 & 0.45 & 0.69 & 0.43 & 0.50 & 0.36 & 0.61 & 0.46 & 0.23 & 0.29 & 0.26 & 0.14 & 0.06 & 0.23 \\
\hline D 9 & & & & & & & & & 1.00 & 0.50 & 0.23 & 0.58 & 0.25 & 0.40 & 0.45 & 0.35 & 0.42 & 0.25 & 0.35 & 0.19 & 0.20 & 0.15 & 0.25 \\
\hline D 10 & & & & & & & & & & 1.00 & 0.59 & 0.61 & 0.39 & 0.53 & 0.47 & 0.55 & 0.54 & 0.40 & 0.46 & 0.36 & 0.23 & 0.15 & 0.25 \\
\hline D 11 & & & & & & & & & & & 1.00 & 0.63 & 0.51 & 0.49 & 0.57 & 0.49 & 0.39 & 0.37 & 0.26 & 0.33 & 0.03 & 0.10 & 0.09 \\
\hline D 12 & & & & & & & & & & & & 1.00 & 0.58 & 0.77 & 0.60 & 0.80 & 0.59 & 0.44 & 0.37 & 0.27 & 0.14 & 0.08 & 0.07 \\
\hline D 13 & & & & & & & & & & & & & 1.00 & 0.63 & 0.52 & 0.53 & 0.49 & 0.57 & 0.45 & 0.45 & 0.19 & 0.16 & 0.22 \\
\hline D 14 & & & & & & & & & & & & & & 1.00 & 0.56 & 0.66 & 0.46 & 0.43 & 0.41 & 0.33 & 0.25 & 0.25 & 0.07 \\
\hline D 15 & & & & & & & & & & & & & & & 1.00 & 0.57 & 0.59 & 0.69 & 0.68 & 0.56 & 0.55 & 0.51 & 0.27 \\
\hline D 16 & & & & & & & & & & & & & & & & 1.00 & 0.75 & 0.63 & 0.53 & 0.38 & 0.27 & 0.24 & 0.18 \\
\hline D 17 & & & & & & & & & & & & & & & & & 1.00 & 0.71 & 0.74 & 0.42 & 0.28 & 0.18 & 0.30 \\
\hline D 18 & & & & & & & & & & & & & & & & & & 1.00 & 0.77 & 0.68 & 0.53 & 0.53 & 0.24 \\
\hline D 19 & & & & & & & & & & & & & & & & & & & 1.00 & 0.55 & 0.46 & 0.47 & 0.22 \\
\hline D 20 & & & & & & & & & & & & & & & & & & & & 1.00 & 0.67 & 0.65 & 0.26 \\
\hline D 21 & & & & & & & & & & & & & & & & & & & & & 1.00 & 0.69 & 0.42 \\
\hline D 22 & & & & & & & & & & & & & & & & & & & & & & 1.00 & 0.43 \\
\hline D 23 & & & & & & & & & & & & & & & & & & & & & & & 1.00 \\
\hline
\end{tabular}




\section{Energy efficiency potential}

The questionnaire of this section focused to know about the deflation of energy usage considering all accessible cost-effective technologies at the industries. Majority of the respondents expressed that 5\%$6 \%$ energy could be conserved with the current technology. Energy efficiency related questions were asked to the participants and usage of energy could be abbreviated by $8 \%-10 \%$ by energy management scheme according to the respondents. The very last query was tied in with rating the noteworthiness of considering a structured perspective for the evaluation options for enhanced energy efficiency. Every participant in this study gave the highest score in this part. However, the respondents suggested considering a system perspective for energy efficiency in the industries.

Relating our findings to textile industries in Bangladesh [3], the improvement indicator is quite significant due to the energy-intensive nature of the industries. This could result in a major reduction in net usage and improvement in energy efficiency. However, there is a significant difference of opinion among the stakeholders as per awareness and policy is concerned. Hence, all the stakeholders agree that overall decisions for assessing the options of energy efficiency is much critical and should be considered from a system perspective.

The "Energy Efficiency and Conservation Masterplan up to 2030" and "Energy Efficiency Action Plan" were prepared by the Sustainable and Renewable Energy Development Authority (SREDA) of Bangladesh, with a target to save 5.3 Mtoe per year, which costs more than a hundred billion Bangladesh Taka (1 USD = 84 Bangladeshi Taka approximately) every year [62]. Guidelines and agenda for the stakeholders at both residential and industrial level, for energy efficiency and management, were proposed, including provisions to provide incentives, tax exemptions, and subsidies to promote the usage of energy-efficient equipment [3]. SREDA, in collaboration with GIZ (a German organisation), published the Energy Auditing Regulations (EAR) in 2016, which considered the environmental issues like global warming, pollution, population, and transportation, that have a direct impact on the economy [62].

\section{Barriers to Energy Service Companies}

\subsection{Analysis of ESCOs by average and frequency of responses}

The barriers to counseling with ESCOs were explored in this research. The participants were requested to rank the hindrances in this regard from "0: Not important" to "1: Extremely important". The ranking of the barriers as per their inclusive average scores and frequencies of responses are presented in Figure 6.

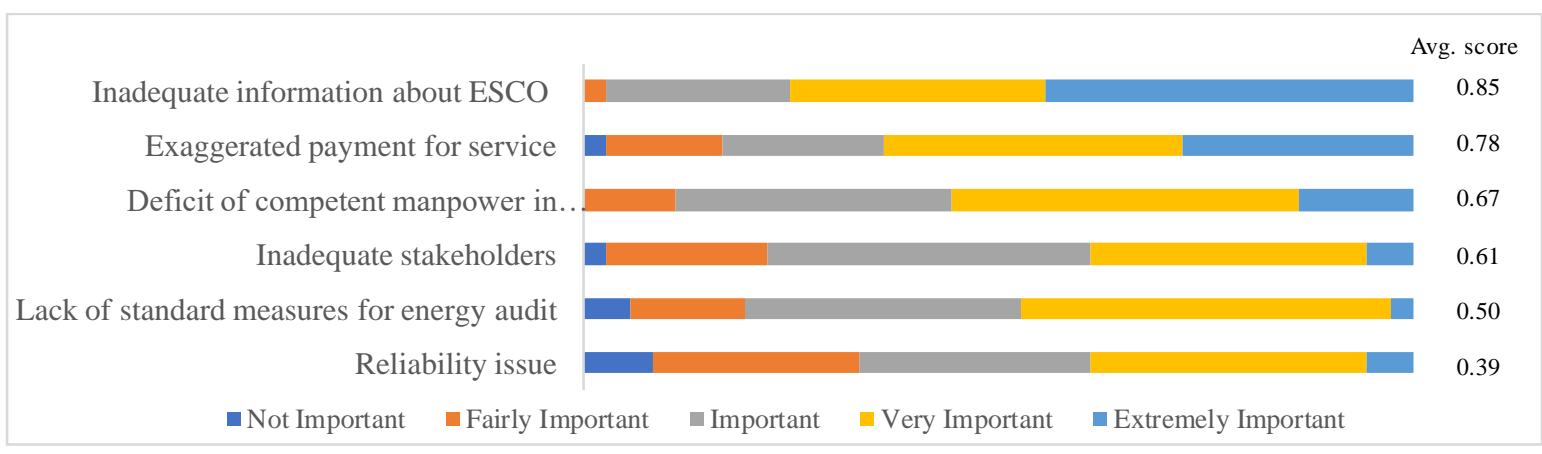

Figure 6: Barriers to counseling ESCOs as per the participants- frequency of responses

The study finds that "Inadequate information about ESCO" is the most significant barrier for consulting ESCOs followed by "Exaggerated payment for service" and "Deficit of competent manpower in the energy management sector". Looking at the result, it can be seen that the industries suffer more in the domain of information and payment issues while incorporating the ESCOs. In fact, most of the 
industries are unaware of ESCO concept. The energy-related issues are taken care of by in-house electrical or mechanical engineers generally. Considering the present economic growth and industrial transformation, there remains a good business prospect in Bangladesh for the ESCOs, if necessary information and supports are provided to the industries.

By looking at the frequency of responses, we can note that 33/36 enterprises expressed their concern at least as important about competent energy management specialist. Indeed, this is a noteworthy point, keeping in mind that the participants are having a significant amount of industrial experience.

Nonetheless, we should acknowledge that very limited literature has addressed the barriers engaging with ESCOs for energy efficiency and energy management initiatives. More importantly, the concept of ESCO is relatively new in Bangladesh [19], which represents an interesting novelty element of the present study. However, when looking at other industrial contexts, a study on the Swedish Policy Program (PFE) indicates that energy efficiency measures are more dependent on management and operations of technologies, rather than the technology itself [92]. Hence, the ESCOs could become a major stakeholder in energy efficiency, having the potential to make significant contributions by following the similar successful approaches from developed countries [96]. Similarly, previous studies conducted in Italy show that ESCOs present a valuable potential in terms of services offered to drive energy efficiency into companies: however, their potential is yet to be clearly acknowledged by the industry [42]. The preliminary findings of our study seem to suggest that the primary barriers can be overcome through the services of the ESCOs. This indicates a potential gap in the energy marketplace of Bangladesh, offering the first-mover's advantage.

\subsection{Correlation analysis of barriers to ESCOs}

By looking at the major correlations in Table 9 (red, "very strong" $>=0.8$; yellow, "strong" $>=0.7$ ), we do not observe any significant finding. Despite this, we can find a slightly interesting relationship between deficit of competent manpower in energy management sector with inadequate stakeholders and lack of standard measure for energy audit with reliability issue. A possible explanation for both of the findings can be drawn:

- The first reflects how the inadequate stakeholders may affect to form expertise in energy management sector.

- The second indicates how the reliability issue may affect standard measures of energy audit.

It should be noted that the studied industries mostly conduct in-house energy audit, as earlier discussed. Therefore, there reliability issue may arise due to energy audit conducted by external stakeholders. However, with our data sample size, caution must be applied, and further research with enlarged sample size could deepen such empirical evidence and explore these preliminary findings. 
Table 9. Total sample analysis of correlations. Significant values are represented in bold

\begin{tabular}{|c|c|c|c|c|c|c|}
\hline & $\begin{array}{l}\text { Inadequate } \\
\text { information } \\
\text { about } \\
\text { ESCO }\end{array}$ & $\begin{array}{l}\text { Exaggerated } \\
\text { payment for } \\
\text { service }\end{array}$ & $\begin{array}{l}\text { Deficit of } \\
\text { competent } \\
\text { manpower } \\
\text { in energy } \\
\text { management } \\
\text { sector }\end{array}$ & $\begin{array}{l}\text { Inadequate } \\
\text { stakeholders }\end{array}$ & $\begin{array}{l}\text { Lack of } \\
\text { standard } \\
\text { measures } \\
\text { for energy } \\
\text { audit }\end{array}$ & $\begin{array}{l}\text { Reliability } \\
\text { issue }\end{array}$ \\
\hline $\begin{array}{l}\text { Inadequate } \\
\text { information about } \\
\text { ESCO }\end{array}$ & 1.00 & 0.09 & 0.34 & 0.11 & 0.17 & 0.13 \\
\hline $\begin{array}{l}\text { Exaggerated } \\
\text { payment for } \\
\text { service }\end{array}$ & & 1.00 & 0.18 & 0.25 & 0.18 & 0.31 \\
\hline $\begin{array}{l}\text { Deficit of } \\
\text { competent } \\
\text { manpower in } \\
\text { energy } \\
\text { management sector }\end{array}$ & & & 1.00 & 0.50 & 0.38 & 0.20 \\
\hline $\begin{array}{l}\text { Inadequate } \\
\text { stakeholders }\end{array}$ & & & & 1.00 & 0.47 & 0.35 \\
\hline $\begin{array}{l}\text { Lack of standard } \\
\text { measures for } \\
\text { energy audit }\end{array}$ & & & & & 1.00 & 0.53 \\
\hline Reliability issue & & & & & & 1.00 \\
\hline
\end{tabular}

\section{Conclusions}

The present study was designed to investigate energy management and its practices, together with barriers and drivers to energy efficiency as well as barriers to ESCOs, in the context of energy intensive industries in a developing Asian economy (Bangladesh) which, to the best of our knowledge, have been largely overlooked so far. Therefore, the results of our investigation could provide significant insights into the energy management domain also for energy policy-makers. As major remark, our empirical findings show that the concept of energy management and energy efficiency is relatively new in the investigated industries, with lack of awareness and information systems deemed as quite critical for companies. This is particularly critical, as awareness on the importance of energy management and energy efficiency constitute a stepping stone for any further improvement project. In addition, we have observed that absence of energy manager or limited authority of energy manager has impact on barriers to energy efficiency. Nonetheless, the significance of energy monitoring has been pointed out, which is essential for increased knowledge and decision making.

Furthermore, our investigated sample revealed an above-average potential of energy efficiency: this important result call for a greater effort by research, policy-making and industry to boost industrial energy efficiency within developing economies, where too little (e.g. small educational projects, financial loans) has been made so far. Nonetheless, industries are still lagging behind in the implementation of energy efficiency solutions and energy management practices. Interestingly, the present study has pointed out that in the investigated context, companies may be challenged, beyond the well-known technical and economic barriers, also by organisational ones. Further, thanks to a preliminary correlation analysis, we have pointed out in the study several potential correlations among barriers and drivers that could give policy-makers valuable insights on the major obstacles and leverages to promote industrial energy management and energy efficiency. Our preliminary results seem to suggest that further policy-making efforts should be placed to better integrate energy management into industries' organisational structures. Likewise, research should further address organisational barriers 
and drivers by understanding their role in the decision-making process of adopting an EEM. Additionally, our exploratory findings in a developing economy suggest that research has not yet thoroughly addressed the supply chain of energy services, to better understand the role of ESCOs in designing, delivering and managing EEMs.

Despite its novel character, the authors would like to acknowledge some study limitations. Firstly, we could not perform intensive statistical tests due to a lesser number of data. Further, we have not conducted a comparison across a number of developing economies within and outside Asia and we have not investigated barriers and drivers with respect to specific EEMs, for which slight differences may be expected.

In conclusion, we believe that our study is a piece of a larger riddle in the perspective of industrial energy management in Bangladesh, as well as for the other emerging economies in Asia, for which larger and deeper research is needed. In this regard, other research methods (e.g., broad survey research methodology) could effectively support broadening the aspects highlighted in this study. Furthermore, deeper statistical analyses could allow more specific insights and deeper understanding about energy management practices in energy intensive industries within emerging economies, as well as barriers and drivers for energy efficiency in those contexts. Additionally, it would be interesting to further explore the role of other contextual factors such as e.g., firm size or presence of an energy manager, in moderating barriers and drivers to energy efficiency, with particular emphasis on organisational issues. Furthermore, in the view of industrial competitiveness and sustainable development, future studies could explore the potential of upcoming Industry 4.0 technologies in supporting the implementation of energy management practices, also measuring with specific performance indicators the improvement of industrial operations.

\section{Reference}

[1] M. A. Moktadir, T. Rahman, M. H. Rahman, S. M. Ali, and S. K. Paul, "Drivers to sustainable manufacturing practices and circular economy: A perspective of leather industries in Bangladesh," J. Clean. Prod., vol. 174, pp. 1366-1380, Jan. 2018, doi: 10.1016/j.jclepro.2017.11.063.

[2] A. S. M. M. Hasan, M. T. Hoq, and P. Thollander, "Energy management practices in Bangladesh's iron and steel industries," Energy Strateg. Rev., vol. 22, pp. 230-236, Nov. 2018, doi: 10.1016/j.esr.2018.09.002.

[3] A. S. M. M. Hasan et al., "Drivers and Barriers to Industrial Energy Efficiency in Textile Industries of Bangladesh," Energies, vol. 12, no. 9, p. 1775, May 2019, doi: 10.3390/en12091775.

[4] A. S. M. M. Hasan, M. A. Kabir, M. T. Hoq, M. T. Johansson, and P. Thollander, "Drivers and barriers to the implementation of biogas technologies in Bangladesh," Biofuels, pp. 1-13, Nov. 2020, doi: 10.1080/17597269.2020.1841362.

[5] "Bangladesh Power Development Board," 2020. [Online]. Available: https://www.bpdb.gov.bd/bpdb_new/index.php/site/area_wise_demand. [Accessed: 14-May2020].

[6] M. A. Habib, M. Hasanuzzaman, M. Hosenuzzaman, A. Salman, and M. R. Mehadi, "Energy consumption, energy saving and emission reduction of a garment industrial building in Bangladesh," Energy, vol. 112, pp. 91-100, Oct. 2016, doi: 10.1016/j.energy.2016.06.062.

[7] H. P. Bedi, “'Our energy, our rights': National extraction legacies and contested energy justice futures in Bangladesh," Energy Res. Soc. Sci., vol. 41, pp. 168-175, Jul. 2018, doi: 10.1016/j.erss.2018.04.009.

[8] P. Rohdin, P. Thollander, and P. Solding, "Barriers to and drivers for energy efficiency in the 
Swedish foundry industry," Energy Policy, vol. 35, no. 1, pp. 672-677, Jan. 2007, doi: 10.1016/j.enpol.2006.01.010.

[9] A. Trianni, E. Cagno, M. Bertolotti, P. Thollander, and E. Andersson, "Energy management: A practice-based assessment model," Appl. Energy, vol. 235, pp. 1614-1636, Feb. 2019, doi: 10.1016/j.apenergy.2018.11.032.

[10] H. Hosseinzadeh-Bandbafha, A. Nabavi-Pelesaraei, M. Khanali, M. Ghahderijani, and K. wing Chau, "Application of data envelopment analysis approach for optimization of energy use and reduction of greenhouse gas emission in peanut production of Iran," J. Clean. Prod., vol. 172, pp. 1327-1335, Jan. 2018, doi: 10.1016/j.jclepro.2017.10.282.

[11] W. Ouyang and J. bo Yang, "The network energy and environment efficiency analysis of 27 OECD countries: A multiplicative network DEA model," Energy, vol. 197, p. 117161, Apr. 2020, doi: 10.1016/j.energy.2020.117161.

[12] P. Thollander, I. L. Svensson, and L. Trygg, "Analyzing variables for district heating collaborations between energy utilities and industries," Energy, vol. 35, no. 9, pp. 3649-3656, Sep. 2010, doi: 10.1016/j.energy.2010.05.009.

[13] Danish, J. Zhang, B. Wang, and Z. Latif, "Towards cross-regional sustainable development: The nexus between information and communication technology, energy consumption, and <scp>CO</scp> 2 emissions," Sustain. Dev., vol. 27, no. 5, pp. 990-1000, Sep. 2019, doi: 10.1002/sd.2000.

[14] E. Cagno and A. Trianni, "Evaluating the barriers to specific industrial energy efficiency measures: An exploratory study in small and medium-sized enterprises," J. Clean. Prod., vol. 82, pp. 70-83, Nov. 2014, doi: 10.1016/j.jclepro.2014.06.057.

[15] P. Thollander and M. Ottosson, "Energy management practices in Swedish energy-intensive industries," J. Clean. Prod., vol. 18, no. 12, pp. 1125-1133, Aug. 2010, doi: 10.1016/j.jclepro.2010.04.011.

[16] E. Cagno, A. Trianni, C. Abeelen, E. Worrell, and F. Miggiano, "Barriers and drivers for energy efficiency: Different perspectives from an exploratory study in the Netherlands," Energy Convers. Manag., vol. 102, pp. 26-38, Sep. 2015, doi: 10.1016/j.enconman.2015.04.018.

[17] A. Trianni, E. Cagno, P. Thollander, and S. Backlund, "Barriers to industrial energy efficiency in foundries: A European comparison,” J. Clean. Prod., vol. 40, pp. 161-176, Feb. 2013, doi: 10.1016/j.jclepro.2012.08.040.

[18] C. Cooremans and A. Schönenberger, "Energy management: A key driver of energy-efficiency investment?," J. Clean. Prod., vol. 230, pp. 264-275, 2019, doi: 10.1016/j.jclepro.2019.04.333.

[19] A. Lawrence, T. Nehler, E. Andersson, M. Karlsson, and P. Thollander, "Drivers, barriers and success factors for energy management in the Swedish pulp and paper industry," J. Clean. Prod., vol. 223, pp. 67-82, Jun. 2019, doi: 10.1016/j.jclepro.2019.03.143.

[20] A. S. M. M. Hasan, R. Hossain, R. A. Tuhin, T. H. Sakib, and P. Thollander, "Empirical Investigation of Barriers and Driving Forces for Efficient Energy Management Practices in Non-Energy-Intensive Manufacturing Industries of Bangladesh," Sustainability, vol. 11, no. 9, p. 2671, May 2019, doi: 10.3390/su11092671.

[21] R. W. Apeaning and P. Thollander, "Barriers to and driving forces for industrial energy efficiency improvements in African industries - a case study of Ghana's largest industrial area," J. Clean. Prod., vol. 53, pp. 204-213, Aug. 2013, doi: 10.1016/j.jclepro.2013.04.003.

[22] S. Z. Abbas, A. Kousar, S. Razzaq, A. Saeed, M. Alam, and A. Mahmood, "Energy 
management in South Asia," Energy Strategy Reviews, vol. 21. Elsevier Ltd, pp. 25-34, 01Aug-2018, doi: 10.1016/j.esr.2018.04.004.

[23] P. Thollander, M. Karlsson, P. Rohdin, J. Wollin, and J. Rosenqvist, "Energy management," in Introduction to Industrial Energy Efficiency, First Edit., Elsevier, 2020, pp. 239-257.

[24] M. Schulze, H. Nehler, M. Ottosson, and P. Thollander, "Energy management in industry - a systematic review of previous findings and an integrative conceptual framework," J. Clean. Prod., vol. 112, pp. 3692-3708, Jan. 2016, doi: 10.1016/j.jclepro.2015.06.060.

[25] A. Kaab, M. Sharifi, H. Mobli, A. Nabavi-Pelesaraei, and K. wing Chau, "Use of optimization techniques for energy use efficiency and environmental life cycle assessment modification in sugarcane production," Energy, vol. 181, pp. 1298-1320, Aug. 2019, doi: 10.1016/j.energy.2019.06.002.

[26] A. Nabavi-Pelesaraei, S. Rafiee, S. S. Mohtasebi, H. Hosseinzadeh-Bandbafha, and K. wing Chau, "Assessment of optimized pattern in milling factories of rice production based on energy, environmental and economic objectives," Energy, vol. 169, pp. 1259-1273, Feb. 2019, doi: 10.1016/j.energy.2018.12.106.

[27] J. C. Brunke, M. Johansson, and P. Thollander, "Empirical investigation of barriers and drivers to the adoption of energy conservation measures, energy management practices and energy services in the Swedish iron and steel industry," J. Clean. Prod., vol. 84, no. 1, pp. 509-525, Dec. 2014, doi: 10.1016/j.jclepro.2014.04.078.

[28] L. B. Christoffersen, A. Larsen, and M. Togeby, "Empirical analysis of energy management in Danish industry," J. Clean. Prod., vol. 14, no. 5, pp. 516-526, Jan. 2006, doi: 10.1016/j.jclepro.2005.03.017.

[29] S. A. Ates and N. M. Durakbasa, "Evaluation of corporate energy management practices of energy intensive industries in Turkey," Energy, vol. 45, no. 1, pp. 81-91, Sep. 2012, doi: 10.1016/j.energy.2012.03.032.

[30] K. Fujisaki, "Energy Management in Industry,” J. Inst. Electr. Eng. Japan, vol. 133, no. 12, pp. 821-824, 2013, doi: 10.1541/ieejjournal.133.821.

[31] S. Backlund, P. Thollander, J. Palm, and M. Ottosson, "Extending the energy efficiency gap," Energy Policy, vol. 51, pp. 392-396, Dec. 2012, doi: 10.1016/j.enpol.2012.08.042.

[32] E. Cagno, A. Neri, and A. Trianni, "Broadening to sustainability the perspective of industrial decision-makers on the energy efficiency measures adoption: some empirical evidence," Energy Effic., vol. 11, no. 5, pp. 1193-1210, Jun. 2018, doi: 10.1007/s12053-018-9621-0.

[33] A. Lawrence, P. Thollander, M. Andrei, and M. Karlsson, "Specific Energy Consumption/Use (SEC) in Energy Management for Improving Energy Efficiency in Industry: Meaning, Usage and Differences," Energies, vol. 12, no. 2, p. 247, Jan. 2019, doi: 10.3390/en12020247.

[34] A. Lawrence, M. Karlsson, and P. Thollander, "Effects of firm characteristics and energy management for improving energy efficiency in the pulp and paper industry," Energy, vol. 153, pp. 825-835, Jun. 2018, doi: 10.1016/j.energy.2018.04.092.

[35] Sandra Backlund; Sarah Broberg; Mikael Ottosson; Patrik Thollander., "Energy efficiency potentials and energy management practices in Swedish firms," in ECEEE Summer Study on Energy Efficiency in Industry, 2012, pp. 669-677.

[36] L. Sivill, J. Manninen, I. Hippinen, and P. Ahtila, "Success factors of energy management in energy-intensive industries: Development priority of energy performance measurement," Int. J. Energy Res., vol. 37, no. 8, pp. 936-951, Jun. 2013, doi: 10.1002/er.2898.

[37] A. Lawrence, P. Thollander, and M. Karlsson, "Drivers, Barriers, and Success Factors for 
Improving Energy Management in the Pulp and Paper Industry," Sustainability, vol. 10, no. 6, p. 1851, Jun. 2018, doi: 10.3390/su10061851.

[38] A. Sannö, M. T. Johansson, P. Thollander, J. Wollin, and B. Sjögren, “Approaching Sustainable Energy Management Operations in a Multinational Industrial Corporation," Sustainability, vol. 11, no. 3, p. 754, Jan. 2019, doi: 10.3390/su11030754.

[39] E. Andersson and P. Thollander, "Key performance indicators for energy management in the Swedish pulp and paper industry," Energy Strateg. Rev., vol. 24, pp. 229-235, Apr. 2019, doi: 10.1016/j.esr.2019.03.004.

[40] E. Cagno, E. Worrell, A. Trianni, and G. Pugliese, "A novel approach for barriers to industrial energy efficiency," Renewable and Sustainable Energy Reviews, vol. 19. Pergamon, pp. 290308, 01-Mar-2013, doi: 10.1016/j.rser.2012.11.007.

[41] E. Cagno, A. Trianni, G. Spallina, and F. Marchesani, "Erratum to: Drivers for energy efficiency and their effect on barriers: empirical evidence from Italian manufacturing enterprises," Energy Effic., vol. 10, no. 4, pp. 871-871, Aug. 2017, doi: 10.1007/s 12053-0169498-8.

[42] A. Trianni, E. Cagno, and S. Farné, "Barriers, drivers and decision-making process for industrial energy efficiency: A broad study among manufacturing small and medium-sized enterprises," Appl. Energy, vol. 162, pp. 1537-1551, Jan. 2016, doi:

10.1016/j.apenergy.2015.02.078.

[43] E. Cagno and A. Trianni, "Exploring drivers for energy efficiency within small- and mediumsized enterprises: First evidences from Italian manufacturing enterprises," Appl. Energy, vol. 104, pp. 276-285, Apr. 2013, doi: 10.1016/j.apenergy.2012.10.053.

[44] H. L. F. de Groot, E. T. Verhoef, and P. Nijkamp, "Energy saving by firms: decision-making, barriers and policies," Energy Econ., vol. 23, no. 6, pp. 717-740, Nov. 2001, doi: 10.1016/S0140-9883(01)00083-4.

[45] M. T. Johansson and P. Thollander, "A review of barriers to and driving forces for improved energy efficiency in Swedish industry- Recommendations for successful in-house energy management," Renewable and Sustainable Energy Reviews, vol. 82. Elsevier Ltd, pp. 618628, 01-Feb-2018, doi: 10.1016/j.rser.2017.09.052.

[46] P. Thollander and M. Ottosson, "An energy efficient Swedish pulp and paper industry Exploring barriers to and driving forces for cost-effective energy efficiency investments," Energy Effic., vol. 1, no. 1, pp. 21-34, Jan. 2008, doi: 10.1007/s12053-007-9001-7.

[47] "Bangladesh Overview." [Online]. Available: https://www.worldbank.org/en/country/bangladesh/overview. [Accessed: 06-Jul-2020].

[48] E. Vine, "An international survey of the energy service company ESCO industry," Energy Policy, vol. 33, no. 5, pp. 691-704, Mar. 2005, doi: 10.1016/j.enpol.2003.09.014.

[49] N. Okay and U. Akman, "Analysis of ESCO activities using country indicators," Renewable and Sustainable Energy Reviews, vol. 14, no. 9. Elsevier Ltd, pp. 2760-2771, 01-Dec-2010, doi: 10.1016/j.rser.2010.07.013.

[50] J. P. Carvallo, S. P. Murphy, E. Stuart, P. H. Larsen, and C. Goldman, "Evaluating project level investment trends for the U.S. ESCO industry: 1990-2017," Energy Policy, vol. 130, pp. 139-161, Jul. 2019, doi: 10.1016/j.enpol.2019.03.061.

[51] S. Bobbino, H. Galván, and M. González-Eguino, "Budget-neutral financing to unlock energy savings potential: An analysis of the ESCO model in Barcelona," in Green Energy and Technology, vol. 164, Springer Verlag, 2015, pp. 183-199. 
[52] Nurcahyanto, Y. Simsek, and T. Urmee, "Opportunities and challenges of energy service companies to promote energy efficiency programs in Indonesia," Energy, vol. 205, p. 117603, May 2020, doi: 10.1016/j.energy.2020.117603.

[53] P. Bertoldi, S. Rezessy, and E. Vine, "Energy service companies in European countries: Current status and a strategy to foster their development," Energy Policy, vol. 34, no. 14, pp. 1818-1832, Sep. 2006, doi: 10.1016/j.enpol.2005.01.010.

[54] E. L. Vine, C. Murakoshi, and H. Nakagami, "International ESCO business opportunities and challenges: A Japanese case study," Energy, vol. 23, no. 6, pp. 439-447, Jun. 1998, doi: 10.1016/S0360-5442(98)00008-5.

[55] Chiharu Murakoshi; Hidetoshi Nakagami, "Current state of ESCO activities in Asia: ESCO industry development programs and future tasks in Asian countries," in ACEEE Summer Studies on Energy Efficiency in Industry, 2009, pp. 311-322.

[56] R. K. Yin, Case Study Research: Design and Methods, Fourth Edi. SAGE Publications, Inc., 2009.

[57] N. Siggelkow, "Persuasion with case studies," Acad. Manag. J., vol. 50, no. 1, pp. 20-24, Feb. 2007, doi: 10.5465/AMJ.2007.24160882.

[58] M. . Patton, Qualitative Evaluation and Research Methods, Second edi. Newbury Park, California: SAGE, 1990.

[59] "Carbon Trust. Energy management- A comprehensive guide to controlling energy use," Carbon Trust. London, United Kingdom, 2011.

[60] A. Mckane, R. Williams, and W. Perry, "Setting the Standard for Industrial Energy Efficiency Permalink," in Proceedings of Conference on Energy Efficiency in Motor Driven Systems, 2008.

[61] S. R. Hossain, I. Ahmed, F. S. Azad, and A. S. M. Monjurul Hasan, "Empirical investigation of energy management practices in cement industries of Bangladesh," Energy, vol. 212, p. 118741, Dec. 2020, doi: 10.1016/j.energy.2020.118741.

[62] "Sustainable \& Renewable Energy Development Authority (SREDA)." [Online]. Available: http://www.sreda.gov.bd/index.php/site/page/82ea-5f0f-bc13-4c81-3875-61c7-1a3d-abe57b58-5ac2. [Accessed: 14-May-2020].

[63] H. C. W. de Vet, L. B. Mokkink, D. G. Mosmuller, and C. B. Terwee, "Spearman-Brown prophecy formula and Cronbach's alpha: different faces of reliability and opportunities for new applications," J. Clin. Epidemiol., vol. 85, pp. 45-49, May 2017, doi: 10.1016/j.jclinepi.2017.01.013.

[64] A. Christmann and S. Van Aelst, "Robust estimation of Cronbach's alpha," J. Multivar. Anal., vol. 97, no. 7, pp. 1660-1674, Aug. 2006, doi: 10.1016/j.jmva.2005.05.012.

[65] E. B. Martin and A. Julian Morris, "Taking Multivariate Statistics out into Industry Multivariate Statistical Progress Control and Process Performance Monitoring,” 1997, pp. 5164.

[66] H. Toutenburg and Shalabh, "Comparison of Two Samples," 2009, pp. 21-43.

[67] A. Hasanbeigi, C. Menke, and P. du Pont, "Barriers to energy efficiency improvement and decision-making behavior in Thai industry," Energy Effic., vol. 3, no. 1, pp. 33-52, Jan. 2010, doi: 10.1007/s12053-009-9056-8.

[68] M. T. Johansson, "Improved energy efficiency within the Swedish steel industry- the importance of energy management and networking," Energy Effic., vol. 8, no. 4, pp. 713-744, Jul. 2015, doi: 10.1007/s12053-014-9317-z. 
[69] F. Backman, "Barriers to Energy Efficiency in Swedish Non-Energy-Intensive Micro- and Small-Sized Enterprises - A Case Study of a Local Energy Program," Energies, vol. 10, no. 1, p. 100, Jan. 2017, doi: 10.3390/en10010100.

[70] E. Andersson, O. Arfwidsson, V. Bergstrand, and P. Thollander, "A study of the comparability of energy audit program evaluations," J. Clean. Prod., vol. 142, pp. 2133-2139, 2017, doi: 10.1016/j.jclepro.2016.11.070.

[71] J. Palm and P. Thollander, "An interdisciplinary perspective on industrial energy efficiency," Appl. Energy, vol. 87, no. 10, pp. 3255-3261, Oct. 2010, doi: 10.1016/j.apenergy.2010.04.019.

[72] R. Ciriminna, F. Meneguzzo, M. Pecoraino, and M. Pagliaro, "Reshaping the education of energy managers," Energy Res. Soc. Sci., vol. 21, pp. 44-48, Nov. 2016, doi: 10.1016/j.erss.2016.06.022.

[73] P. Thollander, S. Backlund, A. Trianni, and E. Cagno, "Beyond barriers - A case study on driving forces for improved energy efficiency in the foundry industries in Finland, France, Germany, Italy, Poland, Spain, and Sweden," Appl. Energy, vol. 111, pp. 636-643, Nov. 2013, doi: 10.1016/j.apenergy.2013.05.036.

[74] D. V. Bush, "The Changing Role of the Energy Manager," Strateg. Plan. Energy Environ., vol. 23, no. 2, pp. 31-39, 2003, doi: 10.1080/10485230309509636.

[75] C. Cooremans, "Make it strategic! Financial investment logic is not enough," Energy Efficiency, vol. 4, no. 4. Springer, pp. 473-492, 21-Nov-2011, doi: 10.1007/s12053-011-91257.

[76] V. António da Silva Gonçalves and F. J. Mil-Homens dos Santos, "Energy management system ISO 50001:2011 and energy management for sustainable development," Energy Policy, vol. 133, p. 110868, Oct. 2019, doi: 10.1016/j.enpol.2019.07.004.

[77] J. M. Sousa Lira, E. G. Salgado, and L. A. Beijo, "Which factors does the diffusion of ISO 50001 in different regions of the world is influenced?," J. Clean. Prod., vol. 226, pp. 759-767, Jul. 2019, doi: 10.1016/j.jclepro.2019.04.127.

[78] H. Kanneganti et al., "Specification of energy assessment methodologies to satisfy ISO 50001 energy management standard," Sustain. Energy Technol. Assessments, vol. 23, pp. 121-135, 2017, doi: 10.1016/j.seta.2017.09.003.

[79] F. Marimon and M. Casadesús, "Reasons to Adopt ISO 50001 Energy Management System," Sustainability, vol. 9, no. 10, p. 1740, Sep. 2017, doi: 10.3390/su9101740.

[80] A. Trianni, E. Cagno, E. Worrell, and G. Pugliese, "Empirical investigation of energy efficiency barriers in Italian manufacturing SMEs," Energy, vol. 49, no. 1, pp. 444-458, Jan. 2013, doi: 10.1016/j.energy.2012.10.012.

[81] "Promoting Energy Efficiency in Bangladesh | Energy Efficiency Case Studies | U.S. Agency for International Development." [Online]. Available: https://www.usaid.gov/energy/efficiency/examples/bangladesh. [Accessed: 14-May-2020].

[82] "Energy Efficiency and Energy Auditing in Bangladesh | Green Growth Knowledge Platform." [Online]. Available: https://www.greengrowthknowledge.org/resource/energy-efficiency-andenergy-auditing-bangladesh. [Accessed: 14-May-2020].

[83] J. Malinauskaite, H. Jouhara, L. Ahmad, M. Milani, L. Montorsi, and M. Venturelli, "Energy efficiency in industry: EU and national policies in Italy and the UK," Energy, vol. 172, pp. 255-269, Apr. 2019, doi: 10.1016/j.energy.2019.01.130.

[84] S. Sorrell, S. Sorrell, J. Schleich, S. Scott, and E. Al., Reducing barriers to energy efficiency in private and public organisations. Final Report. Sussex: Energy Research Centre-Science and 
Technology Policy Research (SPRU). Brighton: University of Sussex; 2000., 2000.

[85] J. Harris, J. Anderson, and W. Shafron, "Investment in energy efficiency: A survey of Australian firms," Energy Policy, vol. 28, no. 12, pp. 867-876, Oct. 2000, doi: 10.1016/S03014215(00)00075-6.

[86] N. Nagesha and P. Balachandra, "Barriers to energy efficiency in small industry clusters: Multi-criteria-based prioritization using the analytic hierarchy process," Energy, vol. 31, no. 12, pp. 1969-1983, Sep. 2006, doi: 10.1016/j.energy.2005.07.002.

[87] A. Trianni and E. Cagno, "Dealing with barriers to energy efficiency and SMEs: Some empirical evidences," Energy, vol. 37, no. 1, pp. 494-504, Jan. 2012, doi: 10.1016/j.energy.2011.11.005.

[88] Y. Fernando and W. L. Hor, "Impacts of energy management practices on energy efficiency and carbon emissions reduction: A survey of malaysian manufacturing firms," Resour. Conserv. Recycl., vol. 126, pp. 62-73, Nov. 2017, doi: 10.1016/j.resconrec.2017.07.023.

[89] A. S. M. M. Hasan and A. Trianni, "A Review of Energy Management Assessment Models for Industrial Energy Efficiency," Energies, vol. 13, no. 21, p. 5713, Nov. 2020, doi: 10.3390/en13215713.

[90] T. Fawcett and G. Killip, "Re-thinking energy efficiency in European policy: Practitioners' use of 'multiple benefits' arguments," J. Clean. Prod., vol. 210, pp. 1171-1179, Feb. 2019, doi: 10.1016/j.jclepro.2018.11.026.

[91] C. Stenqvist and L. J. Nilsson, "Energy efficiency in energy-intensive industries - an evaluation of the Swedish voluntary agreement PFE," vol. 5, no. 2, pp. 225-241, 2012, doi: 10.1007/s12053-011-9131-9.

[92] S. Paramonova, P. Thollander, and M. Ottosson, "Quantifying the extended energy efficiency gap-evidence from Swedish electricity-intensive industries," Renewable and Sustainable Energy Reviews, vol. 51. Elsevier Ltd, pp. 472-483, 29-Jun-2015, doi: 10.1016/j.rser.2015.06.012.

[93] K.-H. Lee, "Drivers and Barriers to Energy Efficiency Management for Sustainable Development," Sustain. Dev., vol. 23, no. 1, pp. 16-25, Jan. 2015, doi: 10.1002/sd.1567.

[94] G. May, I. Barletta, B. Stahl, and M. Taisch, "Energy management in production: A novel method to develop key performance indicators for improving energy efficiency," Appl. Energy, vol. 149, pp. 46-61, 2015, doi: 10.1016/j.apenergy.2015.03.065.

[95] E. Worrell, J. A. Laitner, M. Ruth, and H. Finman, "Productivity benefits of industrial energy efficiency measures," Energy, vol. 28, no. 11, pp. 1081-1098, Sep. 2003, doi: 10.1016/S03605442(03)00091-4.

[96] A. Sa, P. Thollander, and E. Cagno, "Assessing the driving factors for energy management program adoption," Renewable and Sustainable Energy Reviews, vol. 74. Elsevier Ltd, pp. 538-547, 01-Jul-2017, doi: 10.1016/j.rser.2017.02.061. 